\title{
Distribution of lipid biomarkers and carbon isotope fractionation in contrasting trophic environments of the South East Pacific
}

\author{
I. Tolosa ${ }^{1}$, J.-C. Miquel ${ }^{1}$, B. Gasser ${ }^{1}$, P. Raimbault ${ }^{2}$, C. Goyet ${ }^{3}$, and H. Claustre ${ }^{4}$ \\ ${ }^{1}$ International Atomic Energy Agency- Marine Environment Laboratories, 4, quai Antoine 1er, MC 98000, Monaco \\ ${ }^{2}$ Laboratoire d'Océanographie et de Biogéochimie (UMR 6535 CNRS), Centre d'Océanologie de Marseille, Université de la \\ Méditerranée, Campus de Luminy, 13288 Marseille Cx 09, France \\ ${ }^{3}$ BDSI, Université de Perpignan, 52 avenue Paul Alduy, 66860 Perpignan, France \\ ${ }^{4}$ Laboratoire d'Océanographie de Villefranche, Observatoire Océanologique, INSU/CNRS/UPMC, UMR 7093, BP 08, F \\ 06230 Villefranche-sur-Mer, France
}

Received: 28 November 2007 - Published in Biogeosciences Discuss.: 18 December 2007

Revised: 6 May 2008 - Accepted: 27 May 2008 - Published: 30 June 2008

\begin{abstract}
The distribution of lipid biomarkers and their stable carbon isotope composition was investigated on suspended particles from different contrasting trophic environments at six sites in the South East Pacific. High algal biomass with diatom-related lipids (24-methylcholesta5,24(28)-dien-3 $\beta$-ol, $\mathrm{C}_{25}$ HBI alkenes, $\mathrm{C}_{16: 4} \mathrm{FA}, \mathrm{C}_{20: 5} \mathrm{FA}$ ) was characteristic in the upwelling zone, whereas haptophyte lipids (long-chain $\left(\mathrm{C}_{37}-\mathrm{C}_{39}\right)$ unsaturated ketones) were proportionally most abundant in the nutrient-poor settings of the centre of the South Pacific Gyre and on its easter edge. The dinoflagellate-sterol, $4 \alpha$-23,24-trimethylcholest$22(E)$-en-3 $\beta$-ol, was a minor contributor in all of the studied area and the cyanobacteria-hydrocarbon, $\mathrm{C}_{17} n$-alkane, was at maximum in the high nutrient low chlorophyll regime of the subequatorial waters near the Marquesas archipelago.

The taxonomic and spatial variability of the relationships between carbon photosynthetic fractionation and environmental conditions for four specific algal taxa (diatoms, haptophytes, dinoflagellates and cyanobacteria) was also investigated. The carbon isotope fractionation factor $\left(\varepsilon_{p}\right)$ of the 24-methylcholesta-5,24(28)-dien-3 $\beta$-ol diatom marker, varied over a range of $16 \%$ along the different trophic systems. In contrast, $\varepsilon_{p}$ of dinoflagellate, cyanobacteria and alkenone markers varied only by $7-10 \%$. The low fractionation factors and small variations between the different phytoplankton markers measured in the upwelling area likely reveals uniformly high specific growth rates within the four phyto-
\end{abstract}

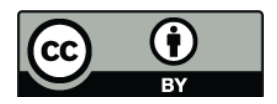

Correspondence to: I. Tolosa

(i.tolosa@iaea.org) plankton taxa, and/or that transport of inorganic carbon into phytoplankton cells may not only occur by diffusion but also by other carbon concentrating mechanisms (CCM). In contrast, in the oligotrophic zone, i.e. gyre and eastgyre, relatively high $\varepsilon_{p}$ values, especially for the diatom marker, indicate diffusive $\mathrm{CO}_{2}$ uptake by the eukaryotic phytoplankton. At these nutrient-poor sites, the lower $\varepsilon_{p}$ values for haptophytes, dinoflagellates and cyanobacteria indicate higher growth rates or major differences on the carbon uptake mechanisms compared to diatoms.

\section{Introduction}

The sustainability of phytoplankton growth in the world ocean is basically controlled by three factors: nutrient abundance, light availability and the response of phytoplankton to these sources (Falkowski, 1984; Falkowski et al., 1998; Irwin et al., 2006; Litchman et al., 2006). The variability of these factors and their role in biogeochemical processes emerge from the properties of the surface mixed layer. Hence, eutrophic areas, such as upwellings, with continuous nutrient supply to the euphotic zone differ strongly from areas with a permanently nutrient-depleted surface layer. In these areas, e.g. oceanic gyres, a deep pycnocline prevents surface waters from a supply with deeper, more nutrient-rich waters.

Photosynthesis is a major biogeochemical process where carbon dioxide and water are converted into organic carbon with the presence of light. The fate of this organic carbon is therefore intimately linked to the conditions of its synthesis and depends strongly on the composition of the

Published by Copernicus Publications on behalf of the European Geosciences Union. 
phytoplankton assemblages. Studying these issues provides essential information for understanding the global marine carbon cycle. In addition to the now widely used chlorophyll and pigment analysis (Barlow et al., 1993; Claustre et al., 2004; Mackey et al., 1996), field data about phytoplankton diversity might also be acquired by the distribution of accessory lipid biomarkers. They provide important information on the phytoplankton composition complementary to that of algal pigments, as well as on the relative importance of carbon sources from heterotrophic bacteria and other zooplankton (Dijkman and Kromkamp, 2006; Pinturier-Geiss et al., 2002; Tolosa et al., 2004).

Isotopic characterization of marine organic matter can provide insight into the conditions under which carbon fixation occurs contributing to the understanding of the global marine carbon cycle. The carbon isotopic composition $\left(\delta^{13} \mathrm{C}\right)$ of any photosynthetic product and its derived carbon isotope fractionation factor $\left(\varepsilon_{p}\right)$ reflects the $\delta^{13} \mathrm{C}$ of the carbon source utilized and the modification by the processes and environmental variables involved in its production: growth rate, temperature, dissolved $\mathrm{CO}_{2}$, cell geometry, irradiance, etc. (Burkhardt et al., 1999a, b; Eek et al., 1999; Hayes, 1993; Laws et al., 1997; Popp et al., 1998b; Rau et al., 1996). For example, high growth rates of the phytoplankton are linked to high $\delta^{13} \mathrm{C}$ values, i.e. they are enriched in ${ }^{13} \mathrm{C}$ (Bidigare et al., 1999; Laws et al., 1995). However, they become depleted in ${ }^{13} \mathrm{C}$ with increasing concentration of dissolved $\mathrm{CO}_{2}$ (Burkhardt et al., 1999a; Riebesell et al., 2000). This latter linkage seems to be limited in its extent, and differences of $\delta^{13} \mathrm{C}$ higher than 1-2\%o cannot be explained any more by the change in the $\mathrm{CO}_{2}$ concentration, but they are rather accounted for by differences in the growth rates of the phytoplankton and in the carbon uptake mechanisms (Bidigare et al., 1997; Burkhardt et al., 1999b, Benthien et al., 2007). Since particulate organic carbon (POC) is a complex mixture of autotrophs, heterotrophs, and detritus, potentially clearer relationships between $\delta^{13} \mathrm{C}$ values and environmental conditions can be obtained using specific biomarkers derived from particular species or taxonomic groups (Bidigare et al., 1999; Pancost et al., 1999; Pancost et al., 1997), compared to the $\delta^{13} \mathrm{C}$ of the bulk POC (Rau et al., 2001; Woodworth et al., 2004). This has become possible with compound-specific isotope-ratio mass spectrometry (Freeman et al., 1990; Hayes et al., 1990).

Our field study uses molecular and stable carbon isotopic ratios of specific lipid biomarkers to evaluate their organic sources and to explore variations in the biogeochemistry of the particulate organic matter in different hydrodynamic and trophic environments from the South East Pacific. These include the eutrophic upwelling area off the Chilean coast, the mesotrophic and HNLC regions south of the equatorial current and the oligotrophic South Pacific Gyre, which was the major focus of this work. The major questions being addressed are:
1. What is the spatial distribution of lipid biomarkers of phyto-, zooplankton and bacteria in the contrasting trophic environments of the South East Pacific?

2. What is the variability of the carbon isotope fractionation $\left(\varepsilon_{p}\right)$ of different phytoplankton taxa in relation to different environmental conditions characterized by nutrient and dissolved inorganic carbon concentrations, and by productivity regimes? We discuss these results with respect to the processes of carbon uptake and assimilation within the different phytoplankton groups.

\section{Materials and methods}

\subsection{Sampling}

Sampling and hydrographic observations were carried on board R/V "L'Atalante" between October and December 2004 and were organized within the framework of the BIOSOPE (Biogeochemistry \& Optics South Pacific Experiment) project which is part of the French JGOFS oceanographic programme PROOF. The main hydrodynamical and trophic features for the different zones are described in Claustre et al. (2008).

Samples were taken at six different sites, so called "long stations", between Tahiti and the Chilean coast (Table 1). The different explored zones exhibited contrasting trophic environments. First, a mesotrophic area downstream of the Marquesas Islands (MAR) and a high nutrient low chlorophyll zone (HNL) upstream of the Islands. Second, an extremely oligotrophic area, very poor in nutrients, located in the centre of the South Pacific Gyre (GYR) and a less oligotrophic site in the east of the gyre (EGY). At the end of the transect, we studied a eutrophic zone highly enriched in nutrients and associated to the upwelling off the Chilean coast (UPW and UPX). UPW station was farther from the coast than UPX and exhibited a more important water stratification.

"Challenger Oceanics" in-situ pumps were used to filter large volumes (400 to 900 liters) of water in the upper $300 \mathrm{~m}$ of the water column, to collect suspended particles through a Nitex screen of $70 \mu \mathrm{m}$ and a precombusted $\left(550^{\circ} \mathrm{C}\right) \mathrm{Mi}-$ croquartz filter (QMF, Sartorius) of $1 \mu \mathrm{m}$ pore size. Only the size fraction collected on the microquartz filter $(1-70 \mu \mathrm{m})$ was analysed.

\subsection{Bulk measurements}

Table 2 summarizes the bulk biochemical parameters of the suspended particulate matter along the transect Marquesas Islands-Chilean coast.

Total $\mathrm{CO}_{2}\left(\mathrm{C}_{T}\right)$ and total alkalinity $\left(\mathrm{A}_{T}\right)$ of water samples were measured by potentiometry (Azouzi et al., 2007) at all sites except UPW. The dissolved $\mathrm{CO}_{2}$ concentration was calculated from $\mathrm{C}_{T}$, alkalinity, temperature, salinity and the 
Table 1. Sampling sites.

\begin{tabular}{lllll}
\hline DATE & Lat. $\left({ }^{\circ} \mathrm{S}\right)$ & Long. $\left({ }^{\circ} \mathrm{W}\right)$ & ACRONYM & Brief description \\
\hline $28 / 10 / 2004$ & 8.4 & 141.3 & MAR & Marquesas Islands characterized by high nutrients high chlorophyll \\
$1 / 11 / 2004$ & 9.0 & 136.8 & HNL & High nutrient low chlorophyll area east of the Marquesas Islands \\
$12 / 11 / 2004$ & 25.6. & 114.0 & GYR & Center of the South Pacific Gyre \\
$28 / 11 / 2004$ & 31.8 & 91.4 & EGY & Eastern border of the Gyre \\
$6 / 12 / 2004$ & 34.0 & 73.3 & UPW & Upwelling area situated above the abyssal plain \\
$10 / 12 / 2004$ & 34.5 & 72.4 & UPX & Upwelling area situated above the continental shelf \\
\hline
\end{tabular}

Table 2. Selected environmental parameters from the six sites at the sampled depths.

\begin{tabular}{|c|c|c|c|c|c|c|c|c|c|c|c|c|}
\hline $\begin{array}{l}\text { locations- } \\
\text { depth (m) }\end{array}$ & $\begin{array}{l}\mathrm{T} \\
{ }^{0} \mathrm{C}\end{array}$ & $\begin{array}{l}\text { density } \\
\mathrm{Kg} \mathrm{m}^{-3}\end{array}$ & $\begin{array}{l}\mathrm{A}_{T}^{\mathrm{a}} \\
\mu \mathrm{mol} \\
\mathrm{Kg}^{-1}\end{array}$ & $\begin{array}{l}\mathrm{C}_{T}^{\mathrm{b}} \\
\mu \mathrm{mol} \\
\mathrm{Kg}^{-1}\end{array}$ & $\begin{array}{l}{\left[\mathrm{CO}_{2}\right](\mathrm{aq})} \\
\mu \mathrm{mol} \\
\mathrm{Kg}^{-1}\end{array}$ & $\begin{array}{l}\mathrm{NO}_{3} \\
\mu \mathrm{mol} \\
1^{-1}\end{array}$ & $\begin{array}{l}\mathrm{PO}_{4} \\
\mu \mathrm{mol} \\
1^{-1}\end{array}$ & $\begin{array}{l}\mathrm{SiOH}_{4} \\
\mu \mathrm{mol} \\
1^{-1}\end{array}$ & $\begin{array}{l}\text { POC } \\
\mu \mathrm{mol} \\
1^{-1}\end{array}$ & $\begin{array}{l}\text { Chl a } \\
\mu \mathrm{g} \\
1^{-1}\end{array}$ & $\begin{array}{l}\mathrm{t}_{p}^{\mathrm{c}} \\
\text { hours }\end{array}$ & $\begin{array}{l}\mathrm{PAR}^{\mathrm{d}} \\
(\%)\end{array}$ \\
\hline mar3-50m & 27.7 & 22.9 & 2363 & 2024 & 11.3 & 1.59 & 0.28 & 1.03 & 1.96 & 0.41 & 12.4 & 2.7 \\
\hline mar3-300 m & 11.3 & 26.6 & 2313 & 2225 & 34.7 & 8.83 & 0.61 & 2.66 & 0.28 & 0.05 & & \\
\hline $\mathrm{hnl} 2-75 \mathrm{~m}$ & 27.3 & 23.2 & 2353 & 2009 & 11.0 & 1.69 & 0.37 & 1.18 & 1.60 & 0.30 & 12.4 & 2.0 \\
\hline gyr2-0 m & 22.0 & 24.6 & 2364 & 2048 & 11.9 & 0.00 & 0.12 & 0.88 & 0.39 & 0.03 & 13.3 & 100 \\
\hline gyr2-75 m & 21.9 & 25.1 & 2369 & 2055 & 11.8 & 0.00 & 0.14 & 1.04 & 0.51 & 0.06 & & 7.5 \\
\hline gyr2-125 m & 20.7 & 25.2 & 2363 & 2051 & 11.7 & 0.00 & 0.12 & 0.96 & 0.49 & 0.13 & & 2.5 \\
\hline gyr2-150 m & 20.3 & 25.3 & 2358 & 2057 & 12.1 & 0.00 & 0.12 & 0.71 & 0.48 & 0.18 & & 0.97 \\
\hline gyr2-175 m & 19.6 & 25.4 & 2347 & 2074 & 13.3 & 0.10 & 0.14 & 0.71 & 0.49 & 0.20 & & 0.32 \\
\hline egy2-200 m & 14.5 & 25.8 & 2271 & 2071 & 16.6 & 2.96 & 0.41 & 1.50 & 0.25 & 0.04 & & \\
\hline egy4-300 m & 10.0 & 26.4 & 2267 & 2119 & 21.8 & 15.4 & 1.07 & 3.99 & 0.23 & 0.03 & & \\
\hline upw1-40 m & 12.8 & 25.9 & & & & 13.0 & 0.91 & 8.00 & 6.92 & 2.50 & 14.3 & 0.15 \\
\hline upw1-100 m & 10.8 & 26.4 & & & & 28.1 & 2.6 & 20.8 & 1.83 & 0.07 & & \\
\hline upw2-300 m & 8.7 & 26.8 & & & & 39.0 & 2.8 & 33.0 & 1.03 & 0.08 & & \\
\hline upx3-40 m & 12.0 & 26.0 & 2274 & 2197 & 37.4 & 22.8 & 2.02 & 10.7 & 3.28 & 0.79 & 14.4 & 0.52 \\
\hline upx2-100 m & 10.5 & 26.4 & 2294 & 2258 & 52.4 & 23.2 & 2.32 & 24.4 & 1.25 & 0.11 & & \\
\hline upx2-300 m & 10.0 & 26.7 & 2307 & 2281 & 56.0 & 35.3 & 3.5 & 27.9 & 0.56 & 0.07 & & \\
\hline
\end{tabular}

${ }^{\mathrm{a}}$ Total alkalinity; ${ }^{\mathrm{b}}$ Total $\mathrm{CO}_{2} ;{ }^{\mathrm{c}}$ day length; ${ }^{\mathrm{d}}$ normalised underwater irradiance

concentrations of silicate and phosphate using the CO2SYS program developed for $\mathrm{CO}_{2}$ system (Lewis and Wallace, 1998). This program is based on equations of the seawater $\mathrm{CO}_{2}$ system (DOE, 1994) and the dissociation constants of Goyet and Poisson (1989).

Nutrient concentrations (nitrate, phosphate and silicate) were determined onboard using an autoanalyzer (Raimbault et al., 2008). Analysis of organic carbon was done with a "Vario EL" elemental analyser ( (C) elementar Analysensysteme $\mathrm{GmbH}$ ) after acidification of the filter subsamples fol- lowing the procedure described in Miquel et al. (1994). The photosynthetically active radiation (PAR) in water was measured using a calibrated hyperspectral profiling radiometer (HyperPro, Satlantic, Inc).

\subsection{Lipid extraction}

Filters containing the suspended particles were spiked with internal standards $\left(n-\mathrm{C}_{24} \mathrm{D}_{50}\right.$, anthracene- $d_{10}$, pyrene- $d_{10}$, perylene- $d_{12}$, friedeline, $5 \alpha$-androstan- $3 \beta$-ol and cholanic 
acid), and extracted by microwave oven with $40 \mathrm{ml}$ of a mixture with $\mathrm{CH}_{2} \mathrm{Cl}_{2} / \mathrm{MeOH}$ (3:1) at $70^{\circ} \mathrm{C}$ for $15 \mathrm{~min}$. Isolation of the neutral and acid lipid fractions were done following the method of Tolosa and de Mora (2004). Extractable lipids were saponified using $1 \mathrm{ml} \mathrm{KOH} \mathrm{6 \%} \mathrm{in} \mathrm{methanol/water}$ (80:20) plus $1 \mathrm{ml}$ of Milli-Q water $\left(80^{\circ} \mathrm{C}, 1 \mathrm{~h}\right)$. Then the neutral fraction was recovered with $n$-hexane and subject to fractionation by HPLC on a normal phase column (Nucleosil column, $20 \mathrm{~cm} \times 0.4 \mathrm{~cm}$ i.d. $5 \mu \mathrm{m}$ ) to isolate the aliphatic hydrocarbons (F1), polycyclic aromatic hydrocarbons (F2), ketone compounds (F3) and sterol and alcohol fraction (F4). Saponified solutions were acidified with $1 \mathrm{ml} \mathrm{HCl} 6 \mathrm{~N}$ to $\mathrm{pH} 2$ and the fatty acids obtained by hydrolysis of wax esters, triacylglycerols, steryl esters and phospholipids were extracted with hexane:ethyl acetate 9:1.

\subsection{Gas chromatography}

The sterol fraction was treated with bis-(trimethylsilyl)trifluoroacetamide (BSTFA) $\left(200 \mu \mathrm{l}, 70^{\circ} \mathrm{C}, 1 \mathrm{~h}\right)$ to convert the alcohols and sterols to their corresponding trimethylsilyl ethers. The acid fraction was derivatised by transesterifying the lipid extract with $500 \mu 1$ of $20 \% \mathrm{BF}_{3}$ in methanol at $80^{\circ} \mathrm{C}$ for $1 \mathrm{~h}$.

Gas chromatography (GC) was performed with a Hewlett Packard HP5890 series II equipped with a flame ionization detector and split/splitless injector. Two fused silica capillary columns were employed: (A) a DB-5 fused silica capillary column $(30 \mathrm{~m} \times 0.25 \mathrm{~mm}$ i.d.; film thickness $0.25 \mu \mathrm{m})$ for neutral compounds and fatty acids and (B) a BPX-70 (SGE, $60 \mathrm{~m} \times 0.32 \mathrm{~mm} \times 0.5 \mu \mathrm{m}$ ) for the fatty acids. Helium was the carrier gas $\left(1.2 \mathrm{ml} \mathrm{min}^{-1}\right)$. The oven temperature for the DB5 was programmed from $60^{\circ} \mathrm{C}(0.5 \mathrm{~min}$ hold $)$ to $290^{\circ} \mathrm{C}$ at $6^{\circ} \mathrm{C} \min ^{-1}$. The GC oven for the BPX-70 column was programmed from $60^{\circ} \mathrm{C}(0.5 \mathrm{~min}$ hold $)$ to $250^{\circ} \mathrm{C}$ at $6^{\circ} \mathrm{C} \mathrm{min}-1$. Injector and detector temperatures were $270^{\circ} \mathrm{C}$ and $320^{\circ} \mathrm{C}$, respectively.

Aliphatic hydrocarbons, ketones, sterols and fatty acids were quantified by internal standards $\left(\mathrm{C}_{24} \mathrm{D}_{50}\right.$, friedeline, $5 \alpha$ androstan- $3 \beta$-ol, and cholanic acid, respectively). Confirmation of peak identity was obtained using GC with mass spectrometric detection (GC-MS) (Hewlett-Packard 5889B MS "Engine") operated in the electron impact at $70 \mathrm{eV}$.

\subsection{Compound-specific isotope analysis}

The lipid biomarkers were analyzed for their stable carbon isotope composition using an HP 5890 GC equipped with a HP 7673 autoinjector and interfaced through a combustion furnace with a FINNIGAN MAT Delta $\mathrm{C}$ isotope ratio mass spectrometer (GC/C/IRMS).

The GC/C/IRMS was equipped with a $100 \%$ methylpolysiloxane fused silica column (Ultra-1, $50 \mathrm{~m} \times 0.32 \mathrm{~mm}$ i.d.; $0.5 \mu \mathrm{m}$ film thickness) pre-connected with a press-fit connector (Supelco, France) to a $0.32 \mathrm{~mm}$ i.d. deactivated fused silica capillary retention gap of $5 \mathrm{~m}$. Injections of $2 \mu \mathrm{l}$ in isooctane were made via an on-column injector. The $\mathrm{GC}$ oven was programmed from 60 to $100^{\circ} \mathrm{C}$ at $10^{\circ} \mathrm{C} \mathrm{min}^{-1}$, then to $310^{\circ} \mathrm{C}$ at $4^{\circ} \mathrm{C} \mathrm{min}{ }^{-1}$ and maintained at $310^{\circ} \mathrm{C}$ for $40 \mathrm{~min}$. Values reported were determined by at least in triplicate to calculate the average and standard deviation. All $\delta^{13} \mathrm{C}$ values are reported in the delta notation relative to the Pee Dee Belemnite (PDB) standard as follows:

$\delta^{13} \mathrm{C}=\left[\left({ }^{13} \mathrm{C} /{ }^{12} \mathrm{C}\right)_{\text {sample }} /\left({ }^{13} \mathrm{C} /{ }^{12} \mathrm{C}\right)_{\mathrm{PDB}}-1\right] \times 10^{3}$

Corrections for the isotopic change introduced in the derivatisation of sterols, fatty alcohols, and fatty acids were determined through derivatisation of standards of known isotopic composition and applying the equation of Jones et al. (1991). Cholesterol, methanol, 18:0 fatty acid and 18:0 FAME of known isotopic carbon composition (measured by elemental analyser coupled to isotope ratio mass spectrometer), were used to calibrate the GC/C/IRMS and correct the isotopic change introduced by the derivatisation. The surrogate standards, $5 \alpha$-androstan- $3 \beta$-ol, cholanic acid and the GC internal standard friedelin of known isotopic composition served as internal isotopic standards.

The precision (standard deviation) for most analytes with GC-C-IRMS signals higher than $0.5 \mathrm{~V}(\mathrm{~m} / \mathrm{z} 44)$ was comparable to the instrument specifications $(0.5 \%)$. As it is illustrated in Appendix $\mathrm{A}$, the major compound 24methylcholesta-5,24(28)-dien-3 $\beta$-ol $\quad\left(\mathrm{C}_{28} \Delta^{5,24(28)}\right)$ stenol was integrated together with their minor stanol pair compound (24-methyl-5 $\alpha$-cholest-24(28)-en-3 $\beta$-ol) to yield a single $\delta^{13} \mathrm{C}$ value for both compounds, because of incomplete chromatographic separation.

2.6 Calculations of carbon isotope fractionation $\left(\varepsilon_{p}\right)$ and sensitivity study

Molecular $\varepsilon_{p}$ was determined following the general Eq (2) outlined in Freeman and Hayes (1992):

$\varepsilon_{p}=\left[\left(\delta^{13} \mathrm{CO}_{2}+1000\right) /\left(\delta^{13} \mathrm{C}_{\mathrm{pp}}+1000\right)-1\right] \times 10^{3}$

where $\mathrm{CO}_{2}$ is its dissolved phase in the water column and $\mathrm{C}_{\mathrm{pp}}$ the primary photosynthate.

In this study, direct measurement of $\delta^{13} \mathrm{CO}_{2}$ was not available. Therefore $\delta^{13} \mathrm{CO}_{2}$ was calculated according to the Eq. (3) of Mook (1974):

$\varepsilon_{b}=\left[\left(\delta^{13} \mathrm{CO}_{2}+1000\right) /\left(\delta^{13} b+1000\right)-1\right] \times 10^{3}=24.12-9866 / T$

where $\varepsilon_{b}$ is the temperature-dependent carbon isotope fractionation of dissolved $\mathrm{CO}_{2}$ with respect to bicarbonate, $T$ is the absolute temperature in Kelvin, and the reference value of $\delta^{13}$ for bicarbonate (b) in sea surface water was taken as $+1.5 \%$ (Quay et al., 2003). We adopt this constant value of $\delta^{13}$ bicarbonate for all sites and depths based on (a) the low variability of $\delta^{13} \mathrm{DIC}$ reported for the surface waters of the global ocean, including Pacific (1.55\%o), Atlantic (1.56\%o) 
an Indian Ocean (1.37\%o) (Quay et al., 2003), (b) the major contribution of bicarbonate in the total DIC pool (90\% of the total) and c) the low variability of $\delta^{13}$ DIC in the upper water column (Kroopnick, 1985). Although meridional $\delta^{13}$ DIC variability is generally greater than zonal variability, surface $\delta^{13} \mathrm{DIC}$ in the Pacific ocean varied only by $0.3 \%$ over the latitudes of the studied area. However, field data of $\delta^{13} \mathrm{C}$ DIC in the Peru upwelling region ranged from -0.65 to $0.81 \%$ (Pancost et al., 1997, Bidigare et al., 1997) whereas in the other areas of the Pacific, it ranged from 1.20 to $1.85 \%$ o (Bidigare et al., 1997). Based on the upper and lower bound values of $\delta^{13}$ DIC, $\varepsilon_{p}$ might have a maximum range variation of $2 \%$ o whereas a typical variation of $\pm 0.5 \%$ results in a variation of $\pm 0.7 \%$ for $\varepsilon_{p}$. Therefore, $\delta^{13}$ DIC do not seem to have major influence on the changing isotopic compositions of organic matter in the upper water column of the ocean, and the likely lower $\delta^{13}$ DIC values for the upwelling site would only accentuate the differences between the trophic environments, providing lower $\varepsilon_{p}$ values for the upwelling sites.

$\delta^{13} \mathrm{C}_{\mathrm{pp}}$ (primary photosynthate) for eukaryotic organisms was calculated by using a constant isotopic fractionation of $4.2 \%$ o between photosynthetic lipids and algal biomass. This value has been provided by Popp et al. (1998a) for alkenones and has been used by other authors (Bidigare et al., 1997; Benthien et al., 2002; Harada et al., 2003; Benthien et al., 2005; Popp et al., 2006a). Similarly, we adopted this value for the isoprenoid compounds, e.g. phytol and sterols, used in previous papers (Pancost et al., 1997; Pancost et al., 1999; Bidigare et al., 1999), thus allowing a comparison of $\varepsilon_{p}$ calculated in the present study. However, the offset in $\delta^{13} \mathrm{C}$ values for common lipids relative to the $\delta^{13} \mathrm{C}$ value of biomass might vary considerably between microalgal species, biosynthetic pathways, the site of reactions in the cell (Schouten et al., 1998; Hayes 2001), and by variations in the relative amounts of the major biochemicals in the cell (i.e., proteins, carbohydrates, and lipids) which in addition have different $\delta^{13} \mathrm{C}$ values. Thus, lower isotopic offsets between lipids and total biomass are expected to occur in nutrient limited environments where higher cellular lipid contents relative to proteins and carbohydrates are found (Livne and Sukenik, 1992). This variability might accentuate the range of $\varepsilon_{p}$ between the trophic environments, with higher $\varepsilon_{p}$ values in low-nutrient waters compared to high-nutrient environments. Potential variations of $\pm 1 \%$ in the isotopic shift between the algal biomass and lipids might result in $\varepsilon_{p}$ variations of $\pm 1 \%$.

Culture studies of haptophytes have identified an isotopic shift ranging from 3.1 to $5.3 \%$ oetween primary photosynthate and alkenone biomarkers (Laws et al., 2001; Riebesell et al., 2000; Jasper and Hayes, 1990; and Popp et al., 1998). In contrast to alkenones, the isotopic offset between algal biomass and other eukaryotic lipid biomarkers is less constrained with reported offsets ranging from -2 to $8 \%$ o for different cultures of phytoplankton taxa (Schoulten et al., 1998; Hayes, 2001). If we consider the upper and lower bound values of offsets found for phytol ( -0.8 to $4.2 \%$ ) and diatom sterols $(0.6$ to $6.4 \%$ ) in marine diatom cultures, the extreme values of $\varepsilon_{p}$ for phytol and diatom sterols differ by 5 and 6\%o respectively. One reported culture of dinoflagellate exhibited an isotopic fractionation between dinosterol and algal biomass of $4.5 \%$ (Schouten et al., 1998).

For prokaryote, $\delta^{13} \mathrm{C}_{\mathrm{pp}}$ was estimated from the $n$ heptadecane assuming a constant isotopic fractionation between photosynthetic lipids and algal biomass of $8.4 \%$ reported by Sakata et al. (1997).

2.7 Estimations of growth rates and intracellular carbon demand in haptophytes assuming purely $\mathrm{CO}_{2}$ diffusion uptake

Carbon isotopic fractionation for phytoplankton $\left(\varepsilon_{p}\right)$ which obtain $\mathrm{CO}_{2}$ by passive diffusion is summarized by the expression of Popp et al. (1998b):

$\varepsilon_{p}=\varepsilon_{f}-\beta \frac{\mu(V / S)}{\left[\mathrm{CO}_{2}\right]}$

where $\varepsilon_{f}$ is the fractionation associated with the enzymecatalyzed carbon fixation step, $\beta$ is a constant, $\mu$ is the specific growth rate, $V$ and $S$ are the volume and surface area of the alga cells and $\left[\mathrm{CO}_{2}\right]$ is the concentration of dissolved $\mathrm{CO}_{2}$ external to the algal cell. Since $\beta$ and (V/S) are practically constant for haptophyte taxa, we can transform this constant to the variable b-value (\%o $\mu \mathrm{mol})$, which serves as a proxy for growth rate and reflects the intracellular carbon demand. This b-value was calculated following the Eq. (5) of Bidigare et al. (1997):

$b=\left(\varepsilon_{f}-\varepsilon_{p}\right) \times\left[\mathrm{CO}_{2}\right]_{\mathrm{aq}}$

with $\varepsilon_{f}$ values of $25 \%$ for eukaryotic algae utilizing Rubisco and $\beta$-carboxylase enzymes (Bidigare et al., 1997) and $\left[\mathrm{CO}_{2}\right]_{\text {aq }}$ calculated as described in Sect. 2.2.

Specific growth rates $\left(\mu,\left(d^{-1}\right)\right)$ of alkenone producing haptophytes were estimated with the following equation found by Bidigare et al. (1997) in laboratory chemostat culture experiments of Emiliania huxleyi:

$\mu_{c c}=\left(25-\varepsilon_{p}\right)\left[\mathrm{CO}_{2}\right] / 138$

and applying the corrections for the effects of day length and respiration on growth rate

$\mu=\left[\mu_{c c} /\left(24 / t_{p}\right)\right] 0.8$

where $\mu$ is the 24 -h average growth rate, $t_{p}$ is day length or photoperiod in hours, and the factor 0.8 adjusts the growth rate for dark respiration.

\section{Results and discussion}

The analytical scheme used in this study identified and quantified $\sim 60$ individual compounds in the neutral lipid fraction and $\sim 40$ compounds in the acid fraction. A summary 
Table 3. Summary of the lipid biomarkers discussed in this study.

\begin{tabular}{|c|c|c|c|}
\hline ACRONYM & COMPOUND NAME(S) & Main diagnostic (and minor) sources & References \\
\hline Phytol & $\begin{array}{l}\text { 3,7,11,15-tetramethyl-2- } \\
\text { hexadecen-1-ol }\end{array}$ & Phototrophic organisms & (Baker and Louda, 1983) \\
\hline $\mathrm{C}_{28} \Delta^{5,24(28)}$ & $\begin{array}{l}\text { 24-methylcholesta-5,24(28)- } \\
\text { dien-3 } \beta \text {-ol }\end{array}$ & Diatoms (flagellates) & (Volkman and Hallegraeff, 1988) \\
\hline $\mathrm{C}_{25} \mathrm{HBI}$ & $\begin{array}{l}\text { Highly branched isoprenoids of } \\
\text { C } 25\end{array}$ & Diatoms (flagellates) & (Volkman et al., 1994) \\
\hline $\mathrm{C}_{16: 4} \mathrm{FA}$ & $\begin{array}{l}\text { 6,9,12,15-hexadecatetraenoic } \\
\text { acid }(\mathrm{C} 16: 4(n-1))\end{array}$ & Diatoms & (Dijkman and Kromkamp, 2006) \\
\hline $\mathrm{C}_{20: 5} \mathrm{FA}$ & $\begin{array}{l}\text { 5,8,11,14,17-eicosopentaenoic } \\
\text { acid }(\mathrm{C} 20: 5(n-3))\end{array}$ & Diatoms (flagellates) & $\begin{array}{l}\text { (Dijkman and Kromkamp, 2006; } \\
\text { Volkman et al., 1989) }\end{array}$ \\
\hline Total alkenones & $\begin{array}{l}\text { Long-chain (C37-C39) unsatu- } \\
\text { rated ketones }\end{array}$ & Haptophytes/Prymnesiophycea & $\begin{array}{l}\text { (Conte et al., 1995; } \\
\text { Volkman et al., 1995) }\end{array}$ \\
\hline $\mathrm{C}_{30} \Delta^{22},($ dinosterol $)$ & $\begin{array}{l}4 \alpha \text {-23,24-trimethylcholest- } \\
22(E) \text {-en-3 } \beta \text {-ol }\end{array}$ & Dinoflagellates & (Robinson et al., 1984) \\
\hline$n-\mathrm{C}_{17}$ & $\mathrm{C}_{17} \quad n$-alkane & Cyanobacteria (green algae) & $\begin{array}{l}\text { (Han and Calvin, 1969; } \\
\text { Winters et al., 1969) }\end{array}$ \\
\hline$n$-alcohols & $\begin{array}{l}n \text {-alkanols, mainly } n \text {-C14, } n \text {-C16 } \\
\text { and } n \text {-C18 }\end{array}$ & $\begin{array}{l}\text { Zooplankton and marine invertebrates } \\
\text { (algae) }\end{array}$ & (Sargent et al., 1977). \\
\hline $\mathrm{C}_{20: 1}+\mathrm{C}_{22: 1} \mathrm{FA}$ & $\begin{array}{l}\text { Long-chain monounsaturated } \\
\mathrm{C}_{20: 1} \text { and } \mathrm{C}_{22: 1} \mathrm{FA}\end{array}$ & Herbivorous mesozooplankton & (Lee et al., 2006) \\
\hline Branched FA & $\begin{array}{l}\text { iso and anteiso branched fatty } \\
\text { acids in the carbon number range } \\
15-19 .\end{array}$ & Heterotrophic bacteria & (Kaneda, 1991) \\
\hline $\mathrm{C}_{27} \Delta^{5},($ cholesterol $)$ & Cholest-5-en- $3 \beta$-ol & Zooplankton (algae) & (Volkman, 1986) \\
\hline Phytosterols & $\begin{array}{l}\text { Includes: } \\
27 \text {-nor-24-methylcholesta- } \\
5,22(E) \text {-dien-3 } \beta \text {-ol; } \\
\text { cholesta-5,22 } E) \text {-dien-3 } \beta \text {-ol; } \\
24 \text {-methylcholesta-5,22 }(E) \text {-dien- } \\
3 \beta \text {-ol; } \\
\mathrm{C}_{28} \Delta^{5,24(28)} \text {; } \\
24 \text {-ethylcholesta-5,22(E)-dien- } \\
3 \beta \text {-ol; } \\
24 \text {-ethylcholest-5-en-3 } \beta \text {-ol and } \\
\mathrm{C}_{30} \Delta^{22}\end{array}$ & Eukaryotic phototrophic organisms & $\begin{array}{l}\text { (Muhlebach and Weber, 1998; } \\
\text { Tolosa et al., 2003) }\end{array}$ \\
\hline
\end{tabular}

of selected lipid biomarkers discussed in this study together with their main sources is shown in Table 3. In particular, we focus on the long-chain unsaturated methylketone $\left(\mathrm{C}_{37: 2}\right.$ alkenone) which is a marker for certain haptophyte algae (Conte et al., 1995, Volkman et al., 1995), the $\mathrm{C}_{28} \Delta^{5.24(28)}$ sterol and HBI which are major components in many diatom (Volkman and Hallegraeff, 1988, Volkman et al., 1994), the dinosterol mainly derived from dinoflagellates (Robinson et al., 1994) and the $n$-C17 alkane derived from cyanobacteria and green algae (Han and Calvin, 1969, Winters et al., 1969). We note, however, that HBIs are not markers for all diatom species since they are mainly synthesized by centric (Rhizosolenia species) and pennate diatoms (Haslea, Navicula and Pleurosigma), whereas $\mathrm{C}_{28} \Delta^{5,24(28)}$ sterol has also been found in some dinoflagellates and green algae (Volkman, 1986). Therefore, there might be an offset between the diatom sterols and the HBIs depending on the diatom species composition. In a similar way, all diatoms do not produce the $\mathrm{C}_{28} \Delta^{5.24(28)}$ sterol, and dinosterol can also be present in certain diatoms (Volkman et al., 1986). Considering that the particle size fraction studied was $1-70 \mu \mathrm{m}$, a certain discrimination of bacterial, diatom and zooplankton biomarkers compared to coccolithophorid and dinoflagellate markers might have occurred. Concentrations of the selected lipid biomarkers are summarized in Table 4 and their concentrations normalized to the POC are shown in Appendix B1. The individual carbon isotope ratio for some of the selected lipid biomarkers are shown in Appendix C1. The complete data set of concentrations and $\delta^{13} \mathrm{C}$ values is available on the BIOSOPE Database: http://www.obs-vlfr.fr/proof/vt/op/ ec/biosope/bio.htm 
Table 4. Selected lipid biomarkers concentrations $\left(\mathrm{ng}^{-1}\right)$ in suspended particles from the South Pacific Ocean.

\begin{tabular}{|c|c|c|c|c|c|c|c|c|c|c|c|c|}
\hline $\begin{array}{l}\text { locations- } \\
\text { depth (m) }\end{array}$ & phytol & $\mathrm{C}_{28} \Delta^{5,24(28)}$ & $\mathrm{C}_{25} \mathrm{HBI}$ & $\begin{array}{l}\mathrm{C}_{16: 4} \\
\mathrm{FA}\end{array}$ & $\begin{array}{l}\mathrm{C}_{20: 5} \\
\mathrm{FA}\end{array}$ & $\begin{array}{l}\text { Total } \\
\text { alkenones }\end{array}$ & $\mathrm{C}_{30} \Delta^{22}$ & $n-\mathrm{C}_{17}$ & $\begin{array}{l}n- \\
\text { alcohols }\end{array}$ & $\begin{array}{l}\mathrm{C}_{20: 1^{+}}+ \\
\mathrm{FA}\end{array}$ & $\begin{array}{l}1 \text { Branched } \\
\text { FA }\end{array}$ & $\mathrm{C}_{27} \Delta^{5}$ \\
\hline mar3-50 m & 31 & 20 & 2.32 & 33 & 98 & 6.5 & 4.4 & 0.13 & 6.7 & 2.8 & 22 & 13 \\
\hline $\operatorname{mar} 3-100 \mathrm{~m}$ & 7.0 & 4.7 & 0.02 & 18 & 36 & 3.7 & 0.0 & 0.04 & 35 & 6.7 & 31 & 6.7 \\
\hline $\operatorname{mar} 3-300 \mathrm{~m}$ & 0.60 & 3.0 & 0.00 & 0.0 & 9.7 & 0.0 & 0.0 & 0.00 & 9.5 & 9.3 & 2.1 & 1.1 \\
\hline $\mathrm{hnl} 2-75 \mathrm{~m}$ & 25 & 30 & 0.80 & 29 & 62 & 16 & 5.7 & 0.25 & 7.3 & 2.3 & 19 & 13 \\
\hline $\mathrm{hnl} 1-100 \mathrm{~m}$ & 21 & 15 & 0.07 & 22 & 54 & 8.8 & 4.0 & 2.3 & 16 & 1.7 & 3.4 & 24 \\
\hline $\mathrm{hnl} 2-300 \mathrm{~m}$ & 0.60 & 1.1 & 0.00 & 0.0 & 5.5 & 0.0 & 0.4 & 0.00 & 10 & 0.47 & 1.2 & 3.8 \\
\hline gyr2-0 m & 1.7 & 1.9 & 0.21 & 1.4 & 8.2 & 14 & 1.6 & 0.00 & 12 & 0.00 & 4.6 & 3.7 \\
\hline gyr2-75 m & 2.3 & 1.9 & 0.02 & 1.4 & 7.2 & 18 & 1.7 & 0.13 & 4.0 & 0.52 & 2.5 & 2.7 \\
\hline gyr2-125 m & 5.6 & 3.2 & 0.03 & 2.4 & 16 & 23 & 2.0 & 0.26 & 4.2 & 0.79 & 3.2 & 4.5 \\
\hline gyr2-150 m & 9.6 & 3.8 & 0.15 & 5.9 & 25 & 16 & 1.1 & 0.29 & 7.5 & 0.46 & 4.6 & 5.7 \\
\hline gyr2-175 m & 9.9 & 4.0 & 0.18 & 3.8 & 16 & 13 & 0.8 & 0.32 & 7.4 & 0.33 & 5.2 & 3.5 \\
\hline gyr2-200 m & 12 & 6.5 & 0.41 & 3.9 & 21 & 6.9 & 1.5 & 0.19 & 9.8 & 0.87 & 5.3 & 7.0 \\
\hline gyr2-300 m & 0.60 & 0.3 & 0.00 & 0.0 & 2.2 & 0.0 & 0.1 & 0.00 & 1.6 & 0.11 & 0.7 & 0.9 \\
\hline egy $4-70 \mathrm{~m}$ & 16 & 20 & 1.40 & 17 & 57 & 20 & 2.8 & 1.2 & 12 & 1.7 & 10 & 15 \\
\hline egy2-200 m & 2.0 & 2.8 & 0.00 & 0.0 & 13 & 1.5 & 0.6 & 0.67 & 9.6 & 0.27 & 4.7 & 7.3 \\
\hline egy4-300 m & 0.60 & 1.4 & 0.00 & 0.0 & 9.4 & 0.5 & 0.6 & 0.00 & 7.0 & 0.00 & 3.1 & 5.6 \\
\hline upw1-40 m & 103 & 55 & 3.69 & 139 & 379 & 27 & 9.7 & 0.23 & 34 & 15.8 & 114 & 36 \\
\hline upw1-100 m & 24 & 15 & 0.09 & 15 & 106 & 7.0 & 3.9 & 0.28 & 34 & 2.5 & 30 & 20 \\
\hline upw2-300 m & 2.8 & 2.5 & 0.00 & 0.0 & 24 & 2.0 & 0.8 & 0.08 & 41 & 1.1 & 10 & 13 \\
\hline upx3-40 m & 79 & 33 & 2.29 & 26 & 143 & 12 & 6.1 & 0.18 & 90 & 7.8 & 57 & 55 \\
\hline upx2-100 m & 26 & 15 & 0.75 & 8.0 & 101 & 2.3 & 3.8 & 0.16 & 10 & 1.4 & 30 & 16 \\
\hline upx2-300 m & 5.7 & 5.2 & 1.73 & 16 & 72 & 1.1 & 1.0 & 0.00 & 215 & 2.6 & 9.4 & 23 \\
\hline
\end{tabular}

3.1 Distribution of phytoplankton, zooplankton and bacterial markers in different trophic environments

Concentrations of phytol, a non-specific marker for phototrophic organisms, if compared at the depth of chlorophyll and POC maxima, were highest at the upwelling sites with $102 \mathrm{ng}^{-1}$ at UPW and $78 \mathrm{ng}^{-1}$ at UPX. The mesotrophic sites, MAR and HNL, exhibited intermediate phytol concentrations of 25 to $31 \mathrm{ng} \mathrm{l}^{-1}$. The lowest values were measured at the oligotrophic sites, EGY $\left(16 \mathrm{ng}^{-1}\right)$ and in particular at GYR (11 $\left.\mathrm{ng} \mathrm{l}^{-1}\right)$, where maximum values of chlorophyll and POC were at $175 \mathrm{~m}$ depth. Concentrations of diatom biomarkers, e.g. $\left(\mathrm{C}_{28} \Delta^{5.24(28)}\right.$ sterol, $\mathrm{C}_{25} \mathrm{HBI}$ alkenes, $\mathrm{C}_{16: 4}$ $\mathrm{FA}, \mathrm{C}_{20: 5} \mathrm{FA}$ ), haptophytes biomarkers (total alkenones) and dinoflagellates markers (dinosterol) exhibited a similar distribution as phytol concentrations (Table 4), except in the Gyre where alkenones and dinosterol peaked at shallower depths than phytol and diatom markers.

Highest concentrations of long-chain $\mathrm{C}_{37}$ and $\mathrm{C}_{38}$ alkenones were measured at the eutrophic UPW site $\left(27 \mathrm{ng}^{-1}\right)$ but also at the two gyre sites EGY $\left(20 \mathrm{ng} \mathrm{l}^{-1}\right)$ and GYR $\left(23 \mathrm{ng} \mathrm{l}^{-1}\right)$. These peak values corresponded to the depth of chlorophyll and POC maxima except for the GYR site where the peak was situated at $125 \mathrm{~m}$ depth, above the chlorophyll maximum but within maximum POC concentrations. A much lower concentration $\left(6.5 \mathrm{ng} \mathrm{l}^{-1}\right)$ was recorded at the MAR site. These values are much lower than those reported for suspended particles from the Bering Sea after blooms of Emiliania huxleyi and ranging from 0.15 to $3.12 \mu \mathrm{g} \mathrm{l}^{-1}$ (Harada et al., 2003), but similar to concentrations observed in suspended particles collected under nonbloom conditions in the surface waters of the North Atlantic and Nordic Sea (Sicre et al., 2002), in the western Sargasso Sea (100 ng $~^{-1}$ ) (Conte et al., 2001) and in the oligotrophic North Pacific subtropical gyre $\left(0.5-15\right.$ ng $^{-1}$ )(Prahl et al., 2005).

The $\mathrm{C}_{17} n$-alkane, which is produced by aerobic photosynthetic bacteria and green algae (Han and Calvin, 1969; Winters et al., 1969) exhibited a maximum concentration of $2.3 \mathrm{ng} \mathrm{l}^{-1}$, below the chlorophyll and POC maxima at the HNL site and of $1.2 \mathrm{ng} \mathrm{l}^{-1}$ at the same depth $(70 \mathrm{~m})$ as chlorophyll and POC maxima at the EGY site. The other sites showed concentration levels below $0.5 \mathrm{ng} \mathrm{l}^{-1}$ (Table 4). These concentrations were consistent with the abundance distribution of prokaryotic phototrophic organisms, with high abundances at the HNL and EGY sites (Grob et al., 2007).

In all samples, the $n$-alkanols were dominated by the shortchain fatty alcohols of even carbon number $(n-\mathrm{C} 14, n-\mathrm{C} 16$ and $n$-C18), which are associated to zooplankton markers (Sargent et al., 1977). With the exception of the two gyre sites (GYR and EGY), maximum concentrations of linear 


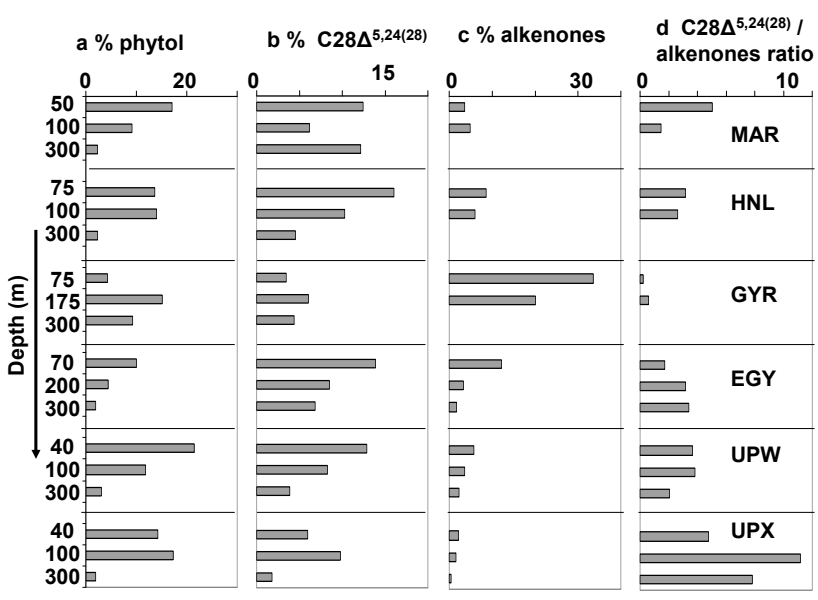

Fig. 1. Percentage contribution of selected lipid biomarkers and biochemical indices: (a) percentage of phytol relative to total neutral lipid concentrations, (b) percentage of 24methylcholesta5,24(28)dien $3 \beta$ ol relative to total neutral lipids concentrations; (c) percentage of total alkenones relative to total neutral lipid concentrations; (d) Ratio of 24 methylcholesta5,24(28)dien $3 \beta$ ol to total alkenones to evaluate the relative contribution of diatoms vs. haptophytes.

alcohols were found below the depth of chlorophyll and POC maxima, at the upwelling sites (UPW, UPX) at $300 \mathrm{~m}$ and at the Marquesas sites (MAR, HNL) at $100 \mathrm{~m}$ depth. In the Gyre, maximum concentrations of $n$-alcohols coincided with the phytol maximum, though another peak $\left(11.6 \mathrm{ng} \mathrm{l}^{-1}\right)$ was registered at the surface of the GYR site. The fatty acids $\mathrm{C}_{20: 1}$ and $\mathrm{C}_{22: 1}$, typical markers of herbivorous mesozooplankton (Graeve et al., 1994, Dalsgaard et al., 2003, Lee et al., 2006), exhibited the highest concentrations at the upwelling sites (UPW, UPX) at the depth of chlorophyll and POC maxima, but also below the euphotic zone $(300 \mathrm{~m})$ at the MAR and UPX sites.

Similar to the phytol distribution, the concentrations of bacterial biomarkers, such as branched fatty acids, were highest at the UPW site (Table 4), whereas the concentrations of zooplankton markers, such as cholesterol and $n$ alcohols exhibited higher abundance at UPX. In general, heterotrophic bacterial populations seemed to be associated to diatom biomass, which is supported by the positive correlation between the $\delta^{13} \mathrm{C}$ of the branched fatty acid $\left(i-\mathrm{C}_{15} \mathrm{FA}\right)$ and the $\delta^{13} \mathrm{C}$ of the $\mathrm{C}_{20: 5} \mathrm{FA}(r=0.81, p<0.05)$.

Some more insight into the phytoplankton distribution may be gained by comparing the relative contribution of the biomarkers within the total neutral lipids, or normalizing their concentrations to the POC content (Appendix B1). Since both approaches provided similar trends, we used the first approach for our discussion illustrated in Fig. 1. The percentage of phototrophic biomarkers generally followed the chlorophyll and POC distribution except at UPX, where phytol and diatom markers peaked at $100 \mathrm{~m}$ depth. Also at HNL, phytol showed relatively high percentages i.e. was enriched

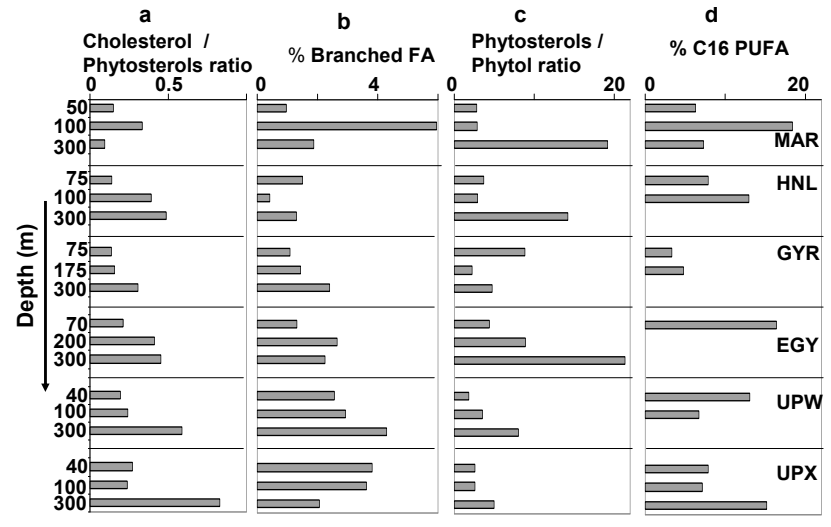

Fig. 2. Values of selected biochemical indices to elucidate the dominant sources in the suspended particles from the different sites. (a) Cholesterol/phytosterols ${ }^{a}$ ratio to evaluate the relative contribution of zooplankton vs. algal. (b) \% Bacterial fatty acid indicator is the sum of all iso and anteiso- branched chain fatty acids expressed as percent of total fatty acids. (c) Phytosterols/phytol ratio to elucidate the degradation state of the phytoplankton material. (d) $\% \mathrm{C}_{16}$ PUFA is the polyunsaturation index of $\mathrm{C}_{16}$ fatty acids to evaluate the ecophysiological state of the marine diatoms.

a Phytosterols are listed in Table 3.

in the POC, down to $100 \mathrm{~m}$ depth. This may be related to the highest relative importance of diatom sterol observed in the euphotic layer (Fig. 1b) and to the presence of diatoms which formed "balls of needles" or clusters (Gómez et al., 2007). In contrast to the diatom biomarkers, the percentage of total alkenones was by far highest in the gyre especially above the chlorophyll maximum (Fig. 1c), where also the concentrations were among the highest of all sites (Table 4). Prymnesiophytes were likely to be the major constituents of eukaryotic phytoplankton in the gyre, suggesting that haptophytes are well adapted to the low nitrate concentrations prevailing in the oligotrophic zone of the Pacific Gyre. Although the lipid content and composition of microalgae can be affected by changes in environmental conditions such as nutrient status, light intensity and temperature (Shifrin and Chrisholm, 1981; Reitan et al., 1994), the $\mathrm{C}_{28} \Delta^{5.24(28)}$ sterol/alkenones ratio may provide us with an overview on the relative contribution of $\mathrm{C}_{28} \Delta^{5.24(28)}$ sterolproducing diatoms to alkenone-producing prymnesiophytes. Highest ratios were obtained at the UPX site, and in particular below the euphotic zone. Alkenone-producing haptophytes predominated over diatoms at the GYR site, especially above the chlorophyll maximum whereas the diatom signal showed a deeper maximum at $175 \mathrm{~m}$ corresponding to the maximum of both phytol and chlorophyll- $a$. Dinosterol showed overall low percentages $(<3 \%)$ or concentrations normalized to POC $\left(<0.37 \mathrm{mg} \mathrm{g}^{-1} \mathrm{C}\right)$, which indicated a minor contribution of dinoflagellates in the algal mixture of these Pacific waters. The highest dinosterol values were recorded in the HNL as it was also confirmed by pigment 
analyses (Ras et al., 2008).

Figure 2 illustrates other diagnostic biomarkers indices to evaluate the relative dominance of zooplankton and bacterial sources within each site as well as the state of the particulate material in the different zones. Although cholesterol is also present in many classes of algae, it is considered a typical marker for zooplankton derived organic matter supply because its concentration becomes enriched after passing the organisms in relation to the algal diet (Harvey et al., 1987). Therefore, the relative abundance of cholesterol over phytosterols has been used as a relative indicator of zooplankton over phytoplankton abundance (Muhleback and Weber, 1998; Tolosa et al., 2003). Here, the cholesterol/phytosterol ratio increased with depth at all sites, and in particular at UPX. This was consistent with the substantial concentrations of $n$-alcohols and zooplanktonic $\mathrm{C}_{20: 1}$ and $\mathrm{C}_{22: 1}$ fatty acids found at $300 \mathrm{~m}$ depth. At most of the sites, the relative importance of bacterial fatty acids was higher below than at the depth of chlorophyll maximum. A contrasting image was observed at UPX where this relative importance was lower. In fact, high bacterial production and a negative net community production were reported from the euphotic zone of UPX (Van Wambeke et al., 2008), which suggests rather "decomposing" conditions compared to "productive" conditions at UPW. At all sites, the ratio of phytosterols/phytol indicated more degraded phytoplankton material at depths below the chlorophyll maximum, but at the gyre site, this was also the case above the maximum. The ratio showed a slightly more degraded material in the euphotic zone of the UPX site as compared to UPW but, at $300 \mathrm{~m}$ depth, fresher material was found at UPX.

The polyunsaturation index of $\mathrm{C}_{16}$ fatty acids (PUFA \% of $\mathrm{C}_{16}$ ) is an indicator of the ecophysiological state of marine diatom populations because storage lipids, mainly $\mathrm{C}_{16: 0}$ and $\mathrm{C}_{16: 1} \mathrm{FA}$, are synthesized during senescence, rather than during logarithmic growth (Shin et al., 2000). The high indices observed in the euphotic zone of the UPW site and at $300 \mathrm{~m}$ depth of UPX suggest that these PUFA originated from diatoms at logarithmic growth. Moreover, the carbon isotope ratios of lipid biomarkers in the euphotic zone were generally more enriched at UPW compared to UPX (Fig. 3), likely indicating higher growth rates at UPW than at UPX. However, below the euphotic zone of UPX, $\delta^{13} \mathrm{C}$ values identified higher growth rates at depth compared to the surface. All these parameter point out that post-bloom conditions with high concentrations of animal-derived detritus prevailed at the surface of the UPX site, whereas the important signal of zooplankton and diatom markers below the euphotic layer indicated the presence of zooplankton feeding on phytoplankton produced during bloom conditions. These findings are supported by the highest particle flux measured at UPX compared to the UPW site (Miquel et al., 2006) and the high concentration of detritus and senescent colonial diatoms observed by microscope in samples from the euphotic zone at the UPX site (Gómez, personal commu-

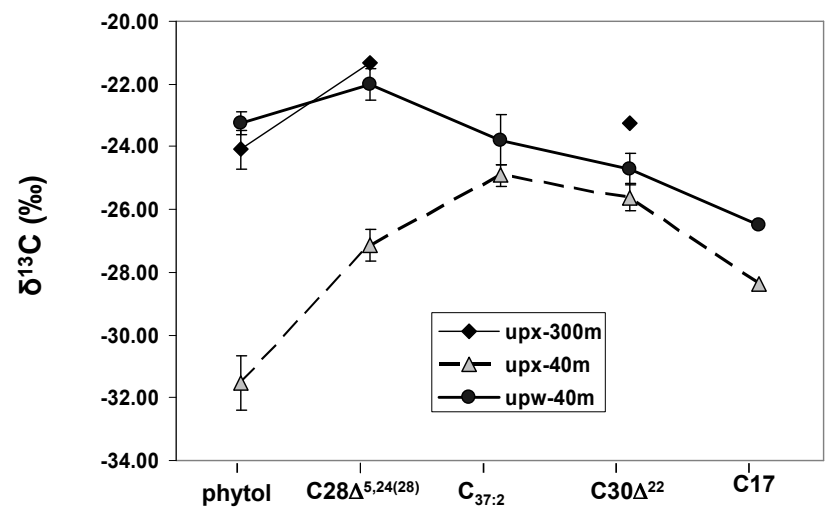

Fig. 3. Carbon isotope ratios $\left(\delta^{13} \mathrm{C}\right)$ for selected lipid biomarkers in the upwelling zone.

nication). These conclusions contrast, however, with those derived from pigment biomarkers (Ras et al., 2008) where UPW site was characteristic of a typically mature bloom of diatoms and the phytoplankton at site UPX was probably at an early stage of development. Also, much higher nutrient concentrations at the surface of UPX site indicated a recent upwelling of deep water. Overall, these contrasted observations might be accounted for by the different turnover and lability between pigment and lipid compounds which represent different pools of the particulate matter. Pigments are relatively more labile and associated with the living material. In contrast, lipids are included in both the living and detrital particulate pools of the matter.

3.2 Vertical distribution of biomarkers in the center of the gyre

Depth profiles of selected accessory lipid biomarkers in suspended matter from the center of the Gyre are presented in Fig. 4. Phytol concentrations showed very low surface values and they were increasing progressively with depth, with maximum concentration at $150-200 \mathrm{~m}$ depth. Relatively high concentrations of $n$-alcohols, cholesterol and branched fatty acids at the surface indicated an important heterotrophic activity in the upper waters. At higher depths $(>75 \mathrm{~m})$, both alcohols and cholesterol showed similar profiles as phytol, likely indicating that here, these biomarkers were mainly phytoplanktonic-derived or that zooplankton biomass was strongly associated with the phytoplankton abundance. Branched fatty acids which are derived from heterotrophic bacteria exhibited the maximum concentration between 150 and $200 \mathrm{~m}$ depth, following the same trend as planktonic biomass. This feature indicates that the bacterial population is associated with the major planktonic biomass.

Other more specific phototrophic biomarkers, such as sterol markers for diatoms exhibited a similar profile as phytol with two maximum at 150 and $200 \mathrm{~m}$ depth. Only few macro diatom species, such as Nitzschia and Dactyliosolen 


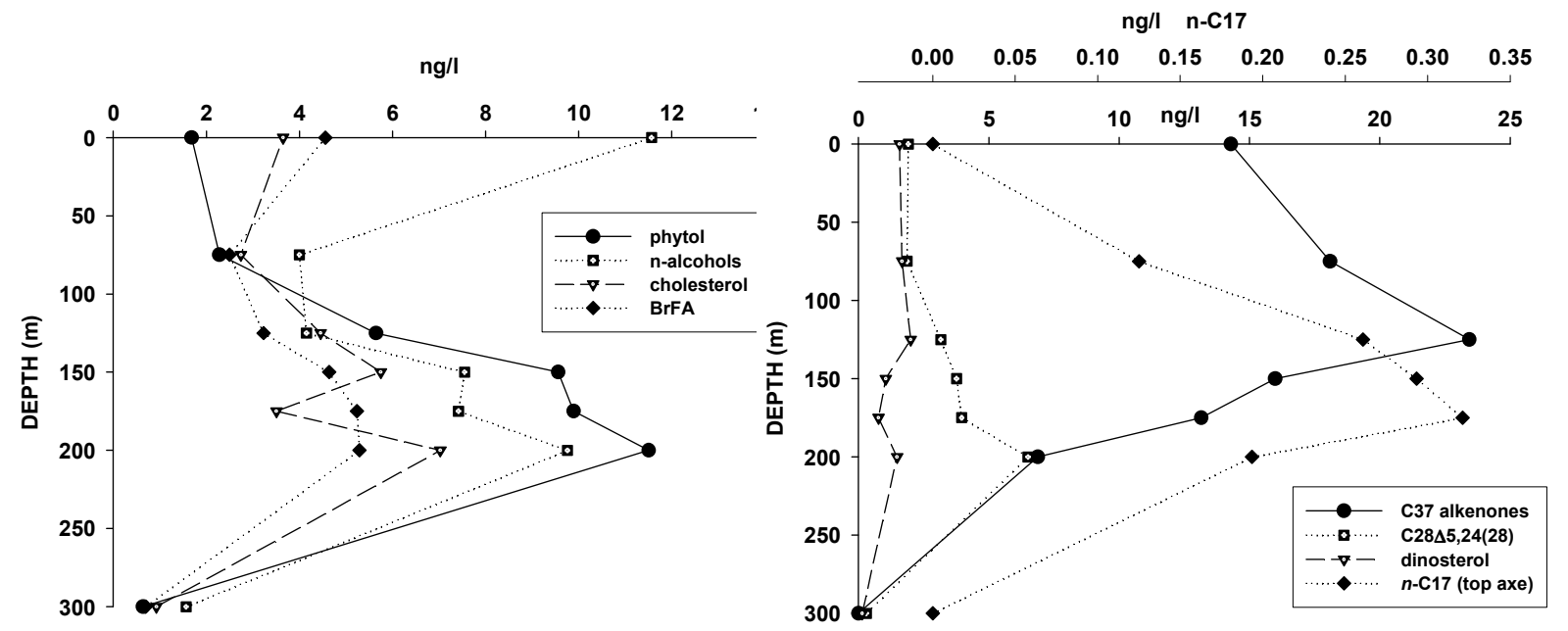

Fig. 4. Depth distribution of selected lipid biomarkers in the suspended particles from the gyre.

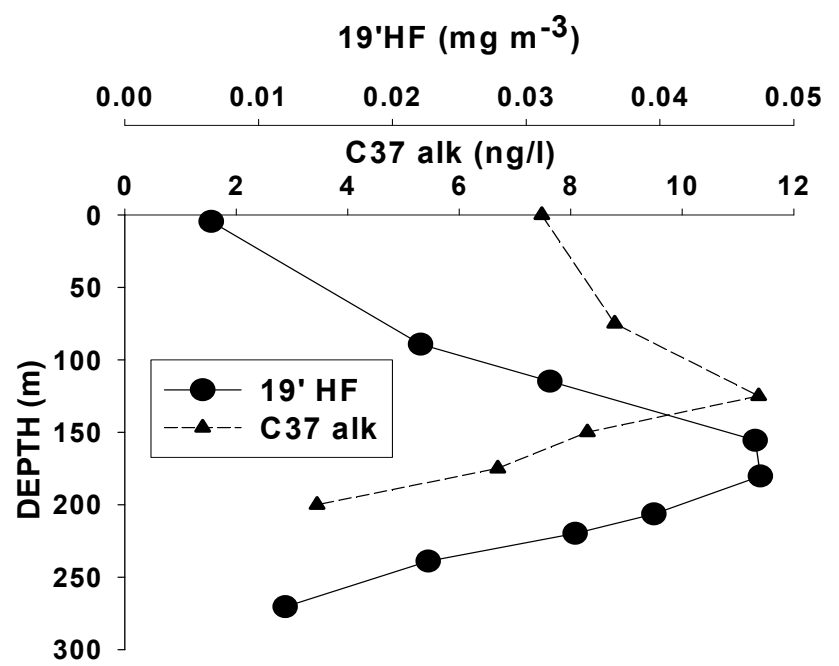

Fig. 5. Profiles for total $\mathrm{C}_{37}$ alkenones concentrations (C37 alk) and 19hexanoyloxyfucoxanthin pigment (19'HF) with depth in the suspended particles from the gyre.

were observed between 200 and $300 \mathrm{~m}$ depth and a significant number of Bacteriastrum associated to a cyanobacteria symbiont was also observed around $140 \mathrm{~m}$ depth (Gómez, personal communication). In contrast, the sterol marker for dinoflagellates exhibited a uniform distribution from surface to $125 \mathrm{~m}$ depth and a deeper maximum concentration at $200 \mathrm{~m}$ depth. Small dinoflagellates were observed in the surface waters of the Gyre center (Gómez, personal communication). The $n$-alkane $\mathrm{C}_{17}$, which is produced by cyanobacteria and other eukaryotic algae, increased with depth showing a maximum concentration between 125 and $175 \mathrm{~m}$. This coincides with the maximum abundances of Prochlorococcus and picoeukaryotes recorded between 100 and $200 \mathrm{~m}$ depth (Grob et al., 2007).
The $\mathrm{C}_{37}$ alkenones, which are specific markers for some algae of the class Haptophyceae/Prymnesiophyceae, including coccolithophorid species such as Emiliania huxleyi, exhibited the maximum concentration above the deep chlorophyll maximum, at $125 \mathrm{~m}$ depth. Cell densities of different coccolithophorid taxa showed, however, different depth profiles, with a maximum peak between $150-200 \mathrm{~m}$ for Emiliania huxleyi whereas other taxa peaked at shallower depths $(\sim 100 \mathrm{~m})$ (Beaufort et al., 2007). These findings indicate that (i) other non-calcifying haptophytes might synthetize alkenones at shallower depths, (ii) that alkenones are not associated with the integrity of coccospheres and/or (iii) that cellular alkenone concentrations varied with the physiological status and species composition of the coccolithophorid assemblage. Furthermore, the concentration of alkenones and the accessory carotenoid 19'Hexanoyloxyfucoxanthin (19'HF) (Ras et al., 2008), characteristics of prymnesiophytes, also exhibited different depth distributions (Fig. 5). Such discrepancy reflects that alkenone-producers in these waters are minor contributors to the 19' HF stock, and that the habitat of alkenone synthesizers diverges from that of the major phytoplankton taxa contributing to the 19'HF distribution. An analogous feature was observed at station ALOHA from the oligotrophic North Pacific Subtropical Gyre (Prahl et al., 2005) and other studies showed that 19'HF abundance was generally not tightly correlated with that of coccolithophorids (Dandonneau et al., 2006). Figure 6 illustrates the carbon isotope composition of the diunsaturated alkenone together with the total concentrations of $\mathrm{C}_{37}$ alkenones. More enriched $\delta^{13} \mathrm{C}$ values were obtained for alkenones measured at the depth of the chlorophyll maximum, whereas the higher concentrations of alkenones found at $125 \mathrm{~m}$ depth were associated to lower $\delta^{13} \mathrm{C}$ values. Change in irradiance could also partially explain the abrupt change of the carbon isotope composition of the alkenones, since lower photon flux density leads to a lower ${ }^{13} \mathrm{C}$ discrimination 


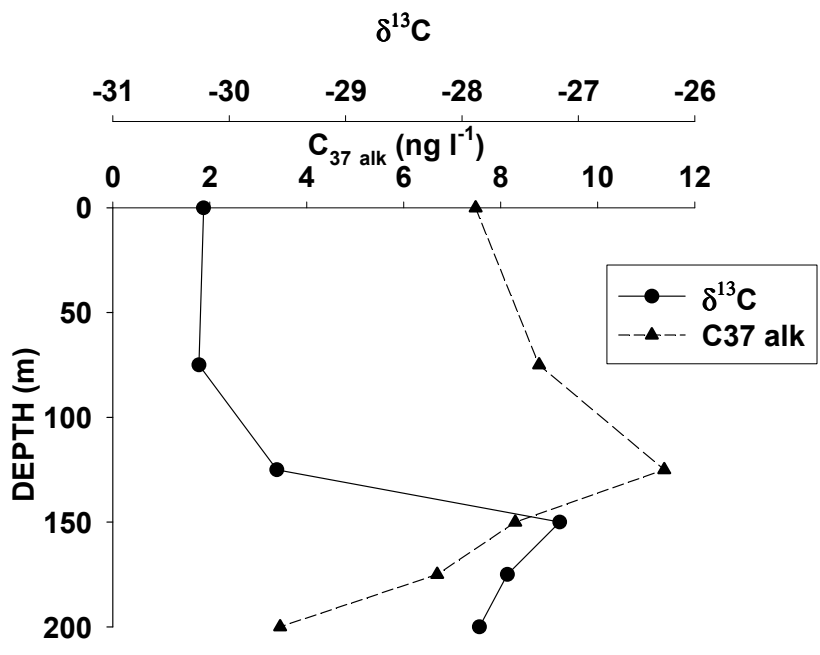

Fig. 6. Profiles for total $\mathrm{C}_{37}$ alkenone concentrations and carbon isotope ratio $\left(\delta^{13} \mathrm{C}\right)$ for the diunsaturated $\mathrm{C}_{37}$ alkenone.

increasing the $\delta^{13} \mathrm{C}$ values (Rost et al., 2002; Thompson and Calvert, 1995). As it is shown in Table 2, the \% PAR values at depths higher than $125 \mathrm{~m}$ were lower than $1 \%$, which would mean that haptophytes were light-limited at these high depths. Consequently, the more enriched $\delta^{13} \mathrm{C}$ values of the alkenone markers at the depth of the chlorophyll maximum might infer that haptophytes are under limited light conditions.

The unsaturation index $\left(\mathrm{U}_{37}^{\mathrm{K}^{\prime}}\right)$ which is widely used as a proxy of sea surface temperature (Prahl and Wakeham, 1987) was calculated as the relative proportion of di-and triunsaturated $\mathrm{C}_{37}$ alkenones. This index was converted to a measure of temperature by the commonly used empirical calibration equation $T=\left(\mathrm{U}_{37}^{\mathrm{K}^{\prime}}-0.039\right) / 0.034$ (Prahl et al., 1988). The derived temperatures (Fig. 7) were 2 to 3 degrees higher than the measured (CTD) temperatures in surface waters. Discrepancies between the alkenone-calculated and observed temperatures might be caused by stress due to nutrient and light limitation and to differences in the stage of the growth cycle (Conte et al., 1998; Epstein et al., 1998; Yamamoto et al., 2000; Prahl et al., 2003), which result in variable alkenone synthesis. Similar observations were reported in winter at ALOHA station (Prahl et al., 2005). They were explained by simply biogeographical variations observed in the alkenone vs. temperature relationship in natural waters, which may reflect differences in genetic and physiological status of the local alkenone-synthesizing populations. Since haptophytes have a low inorganic phosphorous requirement (critical concentrations of $0.2 \mu \mathrm{mol}^{-1}$ ), nitrogen limitation seems likely since inorganic $N$ concentrations at the Gyre stations were well below the half-saturation constant $\left(K_{s}\right.$, the concentration supporting an uptake rate one-half the maximum rate) determined for E. huxleyi $\left(\leq 0.5 \mu \mathrm{moll}^{-1}\right)$ (Eppley et al., 1969). Overall and according to batch cultures

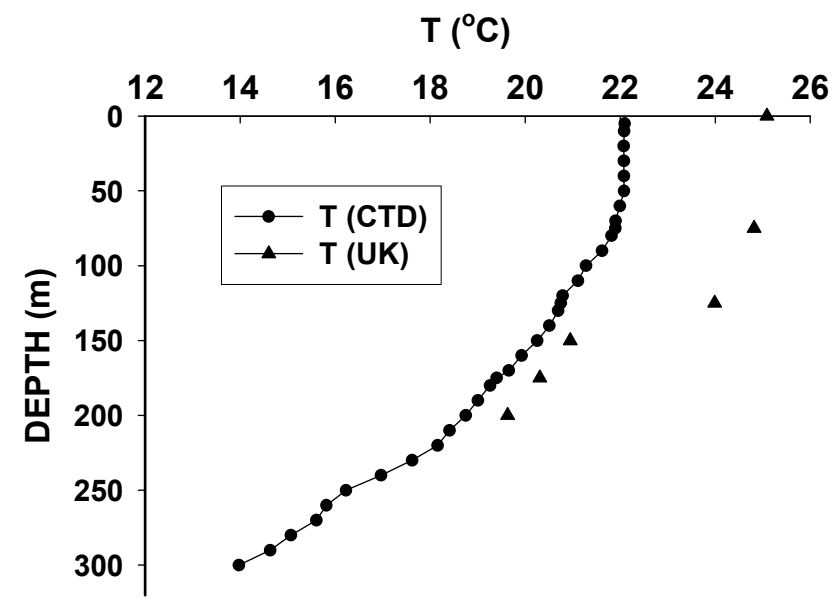

Fig. 7. Profile for CTD temperature and plot for $\mathrm{U}_{37}^{\mathrm{K}^{\prime}}$ derived water temperature estimates (see text for details) from suspended particles in the gyre.

of haptophytes (Epstein et al., 1998), the observed increase in the $\mathrm{U}_{37}^{\mathrm{K}^{\prime}}$ values with the consequent overestimation of the temperatures, might indicate that this marine phytoplankton taxon is under nutrient-limited "stationary growth" conditions. Although other studies showed an overestimation of temperatures in light-limited cultures (e.g. Prahl et al., 2003), we exclude light limitation as the reason for our overestimation. The light levels measured down to $125 \mathrm{~m}$ depth were above light limitation level (Table 2). This overestimation can also be explained by a change in haptophyte ecology towards a dominance of alkenone-producing algae (Prahl et al., 2005; Popp et al., 2006b). Other reasons may be autoxidation of alkenones in these highly irradiated waters (Rontani et al., 2006), and/or degradation of alkenones by aerobic heterotrophic bacteria (Rontani et al., 2008), especially when residence times of particles are long.

\subsection{Biogeochemical implications from carbon isotope frac- tionation}

Stable carbon isotope differences between the inorganic carbon source and that of organic carbon synthesized by autotrophic organisms known as photosynthetic carbon fractionation $\left(\varepsilon_{p}\right)$, can assist in distinguishing between the different $\mathrm{CO}_{2}$ fixation pathways (Table 5). Maximum carbon isotope fractionation of photoautotrophic organisms using the Calvin cycle, like micro-algae and cyanobacteria is in the range of 20 to 27\%o (Popp et al., 1998b; Sakata et al., 1997). However, the $\varepsilon_{p}$ expected for biomarkers derived from eukaryotes can vary between 5 and $25 \%$ o depending basically on $\left[\mathrm{CO}_{2}\right]$, growth rate and the ratio of cellular surface area to volume (Bidigare et al., 1997a; Popp et al., 1998). In contrast, $\varepsilon_{p}$ for prokaryotes (cyanobacteria) ranges between 16 and $22 \%$ because the large surface-to-volume ratio guarantees a large $\mathrm{CO}_{2}$ supply relative to the cellular demand. 
Table 5. Carbon isotope fractionation of $\mathrm{CO}_{2}$ aq with respect to bicarbonate $\left(\varepsilon_{b}\right), \delta^{13} \mathrm{CO}_{2}$ (dissolved in the water column), different carbon isotope fractionation associated with photosynthetic carbon fixation using molecular specific lipid biomarkers ( $\varepsilon_{p}$ of biomarkers) and b-value (\%o $\left.\mu \mathrm{mol} \mathrm{kg}^{-1}\right)$ and specific growth rate for alkenone synthesizers.

\begin{tabular}{|c|c|c|c|c|c|c|c|c|c|}
\hline $\begin{array}{l}\text { locations- } \\
\text { depth (m) }\end{array}$ & $\begin{array}{l}\varepsilon_{b} \\
(\% o)\end{array}$ & $\begin{array}{l}\delta^{13} \mathrm{CO}_{2} \\
(\% \circ)\end{array}$ & $\begin{array}{l}\varepsilon_{p}(\% o) \\
\text { phytol }\end{array}$ & $\begin{array}{l}\varepsilon_{p}(\% \circ) \\
C_{28} \Delta^{5,24(28)}\end{array}$ & $\begin{array}{l}\varepsilon_{p}(\% o) \\
\text { alkenone }\end{array}$ & $\begin{array}{l}\varepsilon_{p}(\% o) \\
\mathrm{C}_{30} \Delta^{22}\end{array}$ & $\begin{array}{l}\varepsilon_{p}(\% o) \\
n-\mathrm{C} 17\end{array}$ & $\begin{array}{c}\mathrm{b}\left(\% \circ \mu \mathrm{mol} \mathrm{kg}^{-1}\right) \\
\text { alkenone }\end{array}$ & $\begin{array}{l}\mu\left(\mathrm{d}^{-1}\right) \\
\text { alkenone }\end{array}$ \\
\hline mar3-50 m & -8.7 & -7.2 & 17.9 & 21.7 & 15.6 & 15.5 & 16.7 & 105 & 0.3 \\
\hline $\mathrm{hnl} 2-75 \mathrm{~m}$ & -8.7 & -7.2 & 16.8 & 23.2 & 16.0 & 14.5 & 18.4 & 99 & 0.3 \\
\hline hnl1-100 m & -8.8 & -7.3 & 19.1 & 23.2 & & 15.7 & & & \\
\hline gyr2-0 m & -9.3 & -7.8 & & & 18.7 & & & 75 & 0.2 \\
\hline gyr2-75 m & -9.3 & -7.8 & & & 18.7 & 18.2 & & 74 & 0.2 \\
\hline gyr2-125 m & -9.5 & -8.0 & 18.1 & 18.6 & 17.8 & 17.6 & & 83 & 0.3 \\
\hline gyr2-150 m & -9.5 & -8.0 & & 22.0 & 15.3 & 17.4 & 9.5 . & 117 & 0.4 \\
\hline gyr2-175 m & -9.6 & -8.1 & 17.9 & 25.5 & 15.7 & & & 124 & 0.4 \\
\hline gyr2-200 m & -9.7 & -8.2 & 18.7 & 23.4 & 15.8 & 19.9 & & 129 & 0.4 \\
\hline egy4-70m & -10.0 & -8.5 & 20.0 & 25.4 & 12.8 & 18.0 & 7.6 & 158 & 0.5 \\
\hline egy2-200 m & -10.2 & -8.7 & & 21.4 & 12.2 & 16.9 & & & \\
\hline egy4-300m & -10.7 & -9.2 & & 19.7 & & & & & \\
\hline upw1-40 m & -10.4 & -8.9 & 10.4 & 9.1 & 10.4 & 11.9 & 9.3 & & \\
\hline upw1-100 m & -10.6 & -9.1 & 10.0 & 7.2 & 10.7 & 9.5 & & & \\
\hline upw2-300 m & -10.9 & -9.4 & & 10.0 & & & & & \\
\hline upx3-40 m & -10.5 & -9.0 & 18.8 & 14.2 & 11.9 & 12.7 & 11.2 & $488(365)^{\mathrm{a}}$ & $1.7(1.2)^{\mathrm{a}}$ \\
\hline upx2-100 m & -10.7 & -9.2 & 18.2 & 9.3 & 12.2 & 9.9 & & & \\
\hline upx2-300 m & -10.7 & -9.3 & 10.8 & 8.0 & & 10.0 & & & \\
\hline
\end{tabular}

a calculated with the $\left[\mathrm{CO}_{2}\right]$ at the surface

Others pathways, apparently restricted to other bacteria, such as anoxygenic phototrophic bacteria, are the reversed tricarboxylic acid cycle and the 3-hydroxypropionate pathway, both of which are characterized by significantly smaller isotope effects ( $\varepsilon_{p}$ of 2-14\%o)(van der Meer et al., 2001).

We observed higher taxonomic variations in $\varepsilon_{p}$ for eukaryotic algae growing in the oligotrophic areas (variations of $\sim 10 \%$ o) compared to the eutrophic sites of the upwelling (variations of 3 to $7 \%$ ). The variation of the carbon isotope fractionation for the diatom marker covered a range of $\sim 16 \%$ olong the different trophic systems. In contrast, $\varepsilon_{p}$ of dinoflagellate and alkenone markers varied much less ca. 10 and $7 \%$, respectively.

Plots of the carbon isotope fractionation of the different eukaryotic markers vs the three major nutrients in the euphotic layer showed similar trends. An example is given in Fig. 8 for the nitrate concentrations, showing a negative logarithmic curve for the diatom biomarker. $\varepsilon_{p}$ values from nutrient-rich waters at eutrophic sites were much lower compared to those in the nitrate limited conditions of the Gyre. However, in oligotrophic waters, the high scatter of $\varepsilon_{p}$ indicates that other factors besides major nutrients are probably affecting the carbon isotope fractionation. This is illustrated by the small effect of nitrate concentrations on the carbon isotope fractionation of the haptophytes (alkenones).

The carbon isotope fractionation of eukaryotic markers showed also a negative trend with $\left[\mathrm{CO}_{2}\right]_{\mathrm{aq}}$ (Fig. 9). These relationships deviate from the previously reported general oceanic trend (Rau et al., 2001) and culture studies (Burkhardt et al., 1999a) where carbon isotope fractionation increases $\left(\delta^{13} \mathrm{C}\right.$ decrease) when $\left[\mathrm{CO}_{2}\right]_{\mathrm{aq}}$ increases. However, this apparent deviation has already been observed in Peruvian upwelling waters where it was suggested that a diatom carbon concentrating mechanism (CCM) was likely the cause of the lower $\varepsilon_{p}$ of diatoms in these waters with high $\left[\mathrm{CO}_{2}\right]_{\mathrm{aq}}$. In the present study, we also observed a small effect of $\left[\mathrm{CO}_{2}\right]_{\mathrm{aq}}$ on isotope fractionation of alkenones, which agrees with other studies that privileged potential changes of $\varepsilon_{p}$ due to growth rate and carbon uptake mechanisms in $E$. huxleyi (Benthien et al., 2007; Bidigare et al., 1997). A similar trend was found between $\left[\mathrm{CO}_{2}\right]$ and the $\varepsilon_{p}$ of $n-\mathrm{C} 17$ (data not shown) which is consistent with a previous work with Popp et al. (1998b) who found for Synechococcus that $\varepsilon_{p}$ is independent of the concentration of dissolved $\mathrm{CO}_{2}$, likely because its cell geometry guarantees a large $\mathrm{CO}_{2}$ supply. 


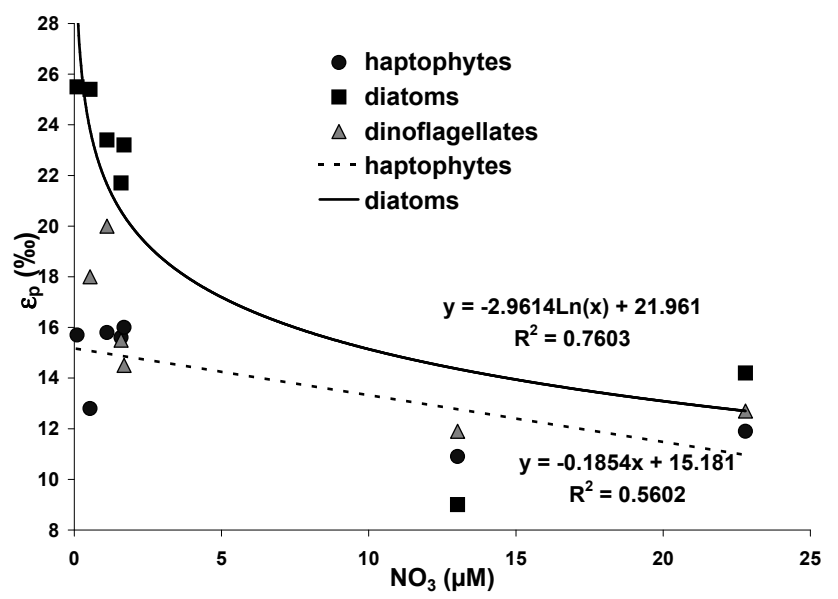

Fig. 8. Carbon isotope fractionation factor of the eukaryotic markers vs. measured nitrate concentrations across the South Pacific Ocean. Logarithmic curve fitting corresponds to diatom marker, linear fitting for haptophytes is shown to illustrate the contrast between diatoms and haptophytes.

Overall, the lower isotope fractionation factors and smaller variations between the different eukaryotic markers measured in the upwelling area might indicate uniformly high growth rates for the three phytoplankton taxa, diatoms, haptophytes and dinoflagellates and/or that phytoplankton may employ carbon concentrating mechanisms (CCM) other than diffusion, which actively transport inorganic carbon into cells. Similar findings were reported by other authors (Pancost et al., 1999; Pancost et al., 1997; Rau et al., 2001; Werne and Hollander, 2004) who invoked that an active transport of bicarbonate into the cell may play a role in the carbon isotope fractionation by phytoplankon in upwelling areas with high concentrations of $\mathrm{CO}_{2}$. Light is another factor which may decrease the carbon isotope fractionation under low saturation levels since it has opposite effects on the $\varepsilon_{p}$ compared to nutrient-limited conditions (Rost et al., 2002, Cassar et al., 2006). However, despite light limiting conditions at $40 \mathrm{~m}$, phytoplankton sampled at theses depths are not necessarily light limited. In hydrodynamically active zones like the upwelling, it can be reasonably admitted that phytoplankton cells produce under light conditions averaged over the mixed layer and not encountered at the depths they were sampled. Hence, it can be excluded that irradiance affected the isotopic fractionation of the different phytoplankton taxa in the upper mixed layer of the upwelling area.

In contrast, the GYR and EGY sites exhibited the highest carbon isotope fractionation factors for eukaryotic algae and in particular for the diatom marker. Their values reached $25-26 \%$ which is close to the maximum isotope fractionation of eukaryotic algae utilizing Rubisco and $\beta$-carboxylase enzymes (Goericke et al., 1994; Laws et al., 1997). Such high $\varepsilon_{p}$ values cannot be obtained by bicarbonate uptake and are indicative of diffusive $\mathrm{CO}_{2}$ uptake. Moreover, ac-

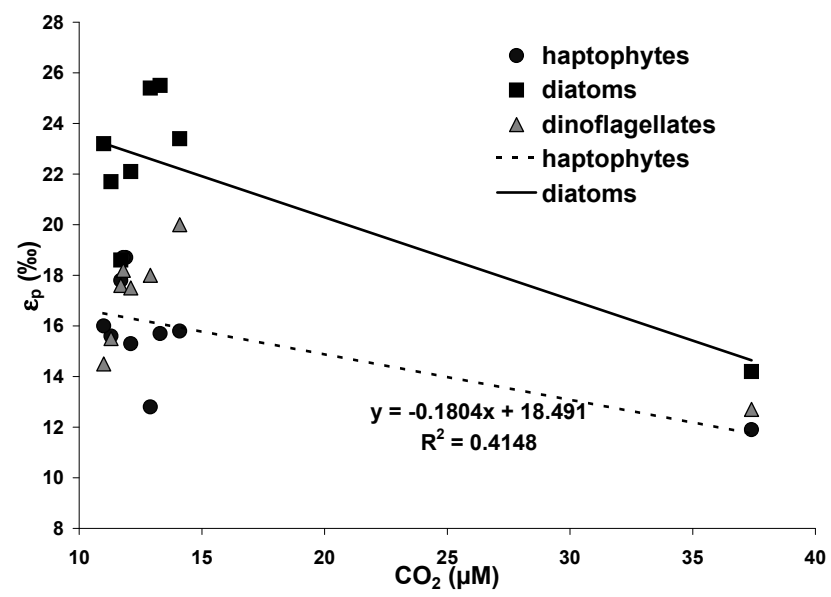

Fig. 9. Carbon isotope fractionation factors of eukaryotic markers vs. $\mathrm{CO}_{2}$ concentrations.

tive uptake of carbon in oligotrophic sites is rather unlikely because of the higher metabolic energy required and CCM may be inhibited by the low oceanic concentrations of certain trace metals (Morel et al., 1994). In these oligotrophic sites, lowest $\varepsilon_{p}$ values were measured for the haptophytes and dinoflagellates, which might infer higher growth rates for these organisms compared to diatoms.

In the mesotrophic areas of the Marquesas Islands (MAR and HNL sites), $\varepsilon_{p}$ values for alkenone producers and dinosterol were also lower than those for diatoms, but still higher than those estimated in the upwelling area. The similar $\varepsilon_{p}$ values for alkenones measured in the poor-nitrated waters of the Gyre and in the high nutrient waters of the HNL site suggest that nitrogen and phosphate are not the limiting nutrients affecting carbon isotope fractionation by the prymnesiophyte algae. This finding contrasts with a study from the NE Pacific where nitrogen starvation seemed to affect the $\varepsilon_{p}$ values for alkenones (Eek et al., 1999) and adds further support to the "trace-metal-growth-rate" hypothesis (Bidigare et al., 1997), which suggested that micronutrients control growth regardless of the concentrations of $\mathrm{PO}_{4}$. Overall, the relatively low $\varepsilon_{p}$ values for alkenones from the oligo- and mesotrophic waters seem to indicate the use of a CCM other than diffusion. However, recent studies provided clear evidence that haptophytes have developed an inefficient but regulated CCM, with a direct uptake of $\mathrm{HCO}_{3}^{-}$(Rost et al., 2003). The highest $\varepsilon_{p}$ for dinoflagellates at the GYR and EGY sites are likely associated to lower growth rates and might be explained by the low $\mathrm{N}: \mathrm{P}$ ratios since optimum dinoflagellate growth occurs at ratios ranging between 6 and 15 (Hodgkiss and Ho, 1997).

The carbon isotope fractionation derived from $n-\mathrm{C}_{17}$ alkane reached the values of $17-19 \%$ in the mesotrophic waters of the HNL and MAR sites, which are within the range of 16-22\%o reported for cyanobacteria biomass (Sakata et al., 1997). In contrast, the low carbon isotope fractionations 
(8 to $12 \%$ ) obtained for $n$-C17 in the oligotrophic waters of the GYR and EGY sites as well as in the eutrophic waters of the upwelling area are suggestive of microorganisms which use $\mathrm{CO}_{2}$-concentrating mechanisms. Despite substantial advances over the past few years, in the understanding of the mechanism and genes involved in cyanobacterial CCMs (Badger and Price, 2003), the induction of the CCM mechanism remains to be determined (McGinn et al., 2003; Woodger et al., 2005). Also, since similar $\varepsilon_{p}$ values were measured in the upwelling area for biomarkers derived from eukaryotic plankton, it cannot be ruled out that $n-\mathrm{C}_{17}$ in the upwelling sites is mainly derived from some eukaryotic source.

The $b$-values and growth rates for alkenone-producing haptophytes measured in the euphotic layer varied almost tenfold, ranging from 75 to $490 \% \mu^{2} \mathrm{~mol} \mathrm{~kg}^{-1}$ and from 0.2 to $1.7 \mathrm{~d}^{-1}$, respectively. The highest growth rates were estimated in the waters of the Chilean upwelling, followed by the EGY $\left(0.5 \mathrm{~d}^{-1}\right)$, the GYR $\left(0.4 \mathrm{~d}^{-1}\right)$ and finally the MAR and HNL $\left(0.3 \mathrm{~d}^{-1}\right)$ sites. The lowest values were found in the surface waters of the Gyre $\left(0.2 \mathrm{~d}^{-1}\right)$. Overall, our $b$-values and growth rates compare to those reported for the Bering Sea, Arabian Sea, Southern Ocean and equatorial Pacific at $140^{\circ} \mathrm{W}\left(84-136 \% \circ \mu \mathrm{mol} \mathrm{kg}^{-1}\right.$ and $0.2-0.4 \mathrm{~d}^{-1}$ ) (Bidigare et al., 1997; Harada et al., 2003; Laws et al., 2001) but they are slightly higher than those reported from the Peru upwelling zone (197-397\% $\mu \mathrm{mol} \mathrm{kg}^{-1}$ and $0.5-1 \mathrm{~d}^{-1}$ ) (Bidigare et al., 1997). This is probably related to the strength of the upwelling as indicated by the higher nutrient and $\mathrm{CO}_{2}$ concentrations in the sampled area and by the larger photoperiod. It is also noteworthy that the calculated growth rates are maximum estimates and are valid only on the assumption that alkenone producing haptophytes obtain $\mathrm{CO}_{2}$ (as the only carbon source) solely by passive diffusion, which may not be the case in the nutrient-rich waters of the upwelling zone. Moreover, alkenones may occur well below the euphotic zone $(40-100 \mathrm{~m})$ in fecal material produced by herbivorous zooplankton (Grice et al., 1998) and other particles, which have been transported down due to physical mixing and sinking. Through the continuous convective movement in the water column of this dynamic area, the phytoplankton cells are likely to encounter lower average $\mathrm{CO}_{2}$ concentrations and higher irradiance than at the depths they were sampled. In this sense, if we consider that alkenones found at depths of 40-100 m were produced in the upper layer where $\mathrm{CO}_{2}$ concentration is lower $\left(\sim 28 \mu \mathrm{mol} \mathrm{kg}{ }^{-1}\right)$ and light is not limited, the estimated growth rate decreases to $1.2 \mathrm{~d}^{-1}$, which is in the range of typical values found in field populations of nutrient rich waters (Bidigare et al., 1997).

The $b$-values for the alkenone synthesizer phytoplankton were well distinguishable between the two contrasting environments: low at the oligotrophic sites and a high value in the upwelling zone. Due to the natural correlation between concentrations of dissolved $\mathrm{CO}_{2}$ and nutrients, $\mathrm{b}$-values obviously co-varied with the concentrations of silicate, ni- trate and phosphate. However, at the very low phosphate levels $\left(<0.4 \mu \mathrm{mol} \mathrm{1}^{-1}\right)$ of the oligotrophic sites, b-values showed relatively high variation $\left(75-160 \% \circ \mu \mathrm{mol} \mathrm{kg}^{-1}\right)$ and compared very well with the corresponding values reported by Bidigare et al. (1997), but also with those from other oligotrophic areas (Laws e al., 2001; Benthien et al., 2002). This confirms the interpretation given by these authors that growth rates may be controlled by some trace micronutrient (e.g. Zn) (Bidigare et al., 1997; Shaked et al., 2006), and/or that adaptation of the phytoplankton physiology to the low nutrient waters might result in higher variability in the efficiency of the different carbon uptake mechanisms.

\section{Summary and conclusions}

As a summary, lipid biomarker abundances together with their relative component contribution confirmed the general expectations on the predominance of diatom algae in nutrient-rich waters, and of zooplankton, bacteria and degraded material below the euphotic zone. In contrast, the hyperoligotrophic area of the Gyre was characterized by low concentrations of lipid biomarkers, and especially by unprecedented deep maxima of eukaryotic markers, and rather unexpectedly high heterotrophic activity in surface waters. Among these biomarkers, phytol and the more specific diatom sterols followed the chlorophyll profile. However, highest concentrations were measured for alkenones with maximum values above chlorophyll maximum and above the concentration peak of 19'HF, thus indicating a quite specific community of the alkenone producing prymnesiophytes. Discrepancies between the alkenone-calculated and the in situ temperatures of the surface layer from the gyre seemed to be caused by nutrient limitation and/or degradation of alkenones. Carbon isotope ratios of alkenones markers evidenced that prymnesiophytes inhabiting the depth of the chlorophyll maximum were likely light-limited.

Our results along the different trophic systems in the South East Pacific showed also that source-specific algal biomarkers and compound specific isotope analyses largely responded to the composition of the phytoplankton and to the different processes of carbon acquisition. Within a probably complex pattern of processes that link the $\varepsilon_{p}$ of the different phytoplankton taxa and their environmental factors, our field study illustrates that carbon isotope fractionation values from nutrient-rich waters were much lower compared to those in nitrate limited. However, the high scatter of $\varepsilon_{p}$ in the oligotrophic conditions indicates that other factors besides major nutrients are probably affecting the carbon isotope fractionation. Light not being generally a limiting factor in the euphotic layer, higher growth rates and/or active uptake of $\mathrm{HCO}_{3}^{-}$could explain the reduced $\varepsilon_{p}$ values of the nutrient-rich waters. These relatively low and similar $\varepsilon_{p}$ over the different phytoplankton taxa of the nutrient-rich waters implied non-diffusive $\mathrm{C}$ transport, whereas the high and 


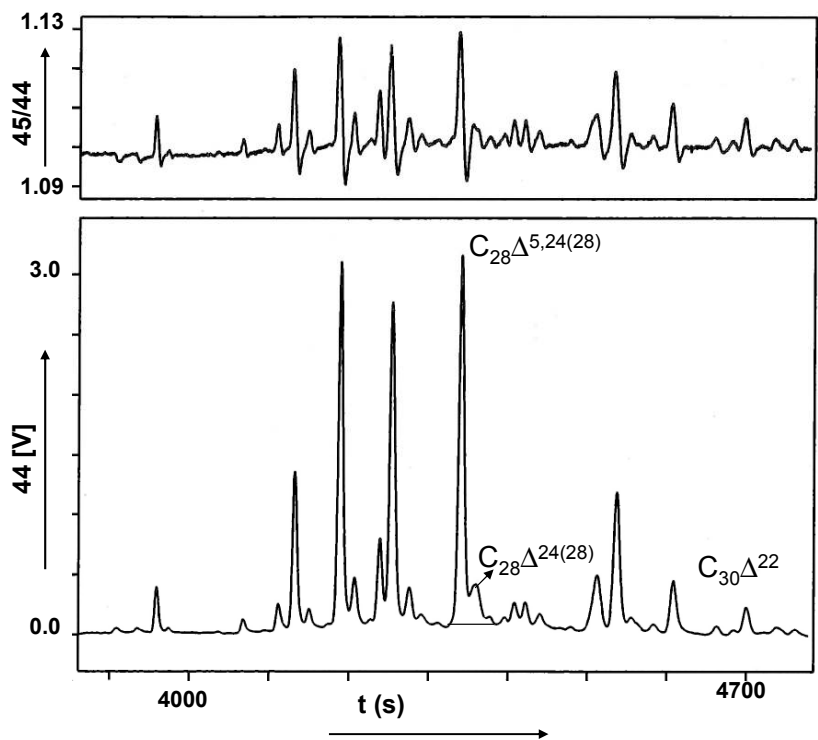

Fig. A1. GC-C-IRMS of the sterol fraction showing the incomplete chromatographic separation of the compound 24methylcholesta-5,24(28)-dien-3 $\beta$-ol $\left(\mathrm{C}_{28} \Delta^{5,24(28)}\right)$ stenol with their minor stanol pair compound (24-methyl-5 $\alpha$-cholest-24(28)en-3 $\beta$-ol, $\left.\mathrm{C}_{28} \Delta^{24(28)}\right)$. Both compounds were integrated together to yield a single $\delta^{13} \mathrm{C}$ value.

dispersed $\varepsilon_{p}$ values from the nutrient-poor waters might result from the lower growth rates and from higher variability in the efficiency of the carbon uptake mechanism by diffusion. However, the available data do not allow distinguishing between the two factors.

Acknowledgements. We thank James Orr and Lamia Azouzi for helpful science discussions. Dominique Tailliez and Claudie Bournot are warmly thanked for their efficient help in CTD rosette management and data processing. A. Benthien and two anonymous reviewers are acknowledged by their valuable suggestions and comments on an earlier version of the manuscript.

This is a contribution of the BIOSOPE project of the LEFECYBER program. This research was funded by the Centre National de la Recherche Scientifique (CNRS), the Institut des Sciences de l'Univers (INSU), the Centre National d'Etudes Spatiales (CNES), the European Space Agency (ESA), The National Aeronautics and Space Administration (NASA) and the Natural Sciences and Engineering Research Council of Canada (NSERC). The IAEA is grateful for the support provided to its Marine Environment Laboratories by the Government of the Principality of Monaco.

Edited by: J. Middelburg

\section{References}

Azouzi, L., Gonçalves Ito, R., Touratier, F., and Goyet, C.: Anthropogenic carbon in the eastern South Pacific Ocean, Biogeosciences Discuss., 4, 1815-1837, 2007, http://www.biogeosciences-discuss.net/4/1815/2007/.

Badger, M. R. and Price, G. D.: $\mathrm{CO}_{2}$ concentrating mechanisms in cyanobacteria: molecular components, their diversity and evolution, J. Exp. Bot., 54, 609-622, 2003.

Baker, E. W. and Louda, J. W.: Thermal aspects in chlorophyll geochemistry. In: Adv. Org. Geochem., 1981, edited by: M. Bjorøy, Wiley, Chichester, 401-421, 1983

Barlow, R. G., Mantoura, R. F. C., Gough, M. A., and Fileman, T. W.: Pigment signatures of the phytoplankton composition in the northeastern Atlantic during the 1990 spring bloom. Deep SeaRes. Pt. II, 40, 459-477, 1993.

Beaufort, L., Couapel, M., Buchet, N., and Claustre, H.: Calcite production by Coccolithophores in the South East Pacific Ocean: from desert to jungle, Biogeosciences Discuss., 4, 3267-3299, 2007 , http://www.biogeosciences-discuss.net/4/3267/2007/.

Benthien, A., Andersen, N., Schulte, S., Müller, P. J., Schneider R. R., and Wefer, G: Carbon isotopic composition of the $C_{37: 2}$ alkenone in core-top sediments of the South Atlantic Ocean: effects of $\mathrm{CO}_{2}$ and nutrient concentrations, Global Biogeochem. Cy., 16, 1012, doi:10.1029/2001GB001433, 2002.

Benthien, A., Andersen, N., Schulte, S., Muller, P. J., Schneider, R. R. and Wefer, G.: The carbon isotopic record of the C37:2 alkenone in the South Atlantic: Last Glacial Maximum (LGM) vs. Holocene, Palaeogeography, Palaeoclimatology, Palaeoecology, 221, 123-140, 2005.

Benthien, A., Zondervan, I., Engel, A., Hefter, J., Terbruggen, A., and Riebesell, U.: Carbon isotopic fractionation during a mesocosm bloom experiment dominated by Emiliania huxleyi: Effects of $\mathrm{CO}_{2}$ concentration and primary production. Geochim. Cosmochim. Ac., 71, 1528-1541, 2007.

Bidigare, R. R., Fluegge, A., Freeman, K. H., Hanson, K. L., Hayes, J. M., Hollander, D., Jasper, J. P., King, L. L., Laws, E. A., Milder, J., Millero, F. J., Pancost, R. D., Popp, B. N., Steinberg, P. A., and Wakeham, S. G.: Consistent fractionation of $\mathrm{C}$ in nature and in the laboratory: growth-rate effects in some haptophyte algae, Global Biogeochem. Cy., 11, 279-292, 1997.

Bidigare, R. R., Hanson, K. L., Buesseler, K. O., Wakeham, S. G., Freeman, K. H., Pancost, R. D., Millero, F. J., Steinberg, P. A., Popp, B. N., Latasa, M., Landry, M. R., and Laws, E. A.: Ironstimulated changes in ${ }^{13} \mathrm{C}$ fractionation and export by equatorial Pacific phytoplankton: Toward a paleogrowth rate proxy, Paleoceanography, 14, 589-595, 1999.

Burkhardt, S., Riebesell, U., and Zondervan, I.: Effects of growth rate, $\mathrm{CO}_{2}$ concentration, and cell size on the stable carbon isotope fractionation in marine phytoplankton, Geochim. Cosmochim. Ac., 63, 3729-3741, 1999a.

Burkhardt, S., Riebesell, U., and Zondervan, I.: Stable carbon isotope fractionation by marine phytoplankton in response to daylength, growth rate, and $\mathrm{CO}_{2}$ availability, Mar. Ecol.-Progr. Ser., 184, 31-41, 1999b.

Cassar, N., Laws, E. A., and Popp, B. N.: Carbon isotopic fractionation by the marine diatom Phaeodactylum tricornutum under nutrient- and light-limited growth conditions, Geochim. Cosmochim Ac, 70, 5323-5335, 2006. 
Table B1. Selected lipid biomarkers concentrations normalized to organic carbon $\left(\mathrm{mg} \mathrm{g}^{-1} \mathrm{C}\right)$ in suspended particles from the South Pacific Ocean.

\begin{tabular}{|c|c|c|c|c|c|c|c|c|c|c|c|c|}
\hline $\begin{array}{l}\text { locations- } \\
\text { depth (m) }\end{array}$ & phytol & $\mathrm{C}_{28} \Delta^{5.24(28)}$ & $\mathrm{C}_{25} \mathrm{HBI}$ & $\begin{array}{l}\mathrm{C}_{16: 4} \\
\mathrm{FA}\end{array}$ & $\begin{array}{l}\mathrm{C}_{20: 5} \\
\mathrm{FA}\end{array}$ & $\begin{array}{l}\text { Total } \\
\text { alkenones }\end{array}$ & $\mathrm{C}_{30} \Delta^{22}$ & $n-\mathrm{C}_{17}$ & $\begin{array}{l}n- \\
\text { alcohols }\end{array}$ & $\begin{array}{l}\mathrm{C}_{20: 1}+ \\
\mathrm{C}_{22: 1} \\
\mathrm{FA}\end{array}$ & $\begin{array}{l}\text { Branched } \\
\text { FA }\end{array}$ & $\mathrm{C}_{27} \Delta^{5}$ \\
\hline $\operatorname{mar} 3-50 \mathrm{~m}$ & 1.3 & 0.87 & 0.10 & 1.4 & 4.2 & 0.28 & 0.19 & 0.01 & 0.28 & 0.12 & 0.92 & 0.55 \\
\hline $\operatorname{mar} 3-100 \mathrm{~m}$ & 0.65 & 0.44 & 0.00 & 1.6 & 3.3 & 0.34 & 0.00 & 0.00 & 3.2 & 0.62 & 2.9 & 0.62 \\
\hline $\operatorname{mar} 3-300 \mathrm{~m}$ & 0.18 & 0.89 & 0.00 & 0.00 & 2.9 & 0.00 & 0.00 & 0.00 & 2.8 & 2.8 & 0.63 & 0.33 \\
\hline hnl2-75 m & 1.3 & 1.5 & 0.04 & 1.5 & 3.2 & 0.83 & 0.30 & 0.01 & 0.38 & 0.12 & 1.0 & 0.68 \\
\hline hnl1-100 m & 1.9 & 1.4 & 0.01 & 2.1 & 5.0 & 0.81 & 0.37 & 0.21 & 1.5 & 0.16 & 0.31 & 2.2 \\
\hline $\mathrm{hnl} 2-300 \mathrm{~m}$ & 0.22 & 0.40 & 0.00 & 0.00 & 2.0 & 0.00 & 0.14 & 0.00 & 3.6 & 0.17 & 0.43 & 1.4 \\
\hline gyr2-0 m & 0.36 & 0.41 & 0.04 & 0.30 & 1.7 & 3.1 & 0.34 & 0.00 & 2.5 & 0.00 & 0.98 & 0.79 \\
\hline gyr2-75 m & 0.38 & 0.31 & 0.00 & 0.23 & 1.2 & 3.0 & 0.28 & 0.02 & 0.65 & 0.08 & 0.41 & 0.44 \\
\hline gyr2-125 m & 0.95 & 0.54 & 0.01 & 0.41 & 2.8 & 4.0 & 0.34 & 0.04 & 0.71 & 0.13 & 0.54 & 0.77 \\
\hline gyr2-150 m & 1.7 & 0.66 & 0.03 & 1.0 & 4.4 & 2.8 & 0.19 & 0.05 & 1.3 & 0.08 & 0.80 & 0.99 \\
\hline gyr2-175 m & 1.7 & 0.68 & 0.03 & 0.65 & 2.7 & 2.2 & 0.14 & 0.05 & 1.3 & 0.06 & 0.88 & 0.60 \\
\hline gyr2-200 m & 2.7 & 1.5 & 0.09 & 0.90 & 4.8 & 1.6 & 0.35 & 0.04 & 2.3 & 0.20 & 1.2 & 1.6 \\
\hline gyr2-300 m & 0.42 & 0.21 & 0.00 & 0.00 & 1.5 & 0.00 & 0.07 & 0.00 & 1.1 & 0.08 & 0.49 & 0.63 \\
\hline egy4-70 m & 1.4 & 1.8 & 0.12 & 1.5 & 5.0 & 1.7 & 0.25 & 0.10 & 1.0 & 0.15 & 0.89 & 1.3 \\
\hline egy2-200 m & 0.67 & 0.93 & 0.00 & 0.00 & 4.3 & 0.50 & 0.20 & 0.22 & 3.2 & 0.09 & 1.6 & 2.4 \\
\hline egy4-300 m & 0.22 & 0.51 & 0.00 & 0.00 & 3.4 & 0.18 & 0.22 & 0.00 & 2.5 & 0.00 & 1.1 & 2.0 \\
\hline upw1-40 m & 1.2 & 0.67 & 0.04 & 1.7 & 4.6 & 0.33 & 0.12 & 0.00 & 0.40 & 0.19 & 1.4 & 0.44 \\
\hline upw1-100 m & 1.1 & 0.69 & 0.00 & 0.69 & 4.8 & 0.32 & 0.18 & 0.01 & 1.5 & 0.11 & 1.3 & 0.91 \\
\hline upw2-300 m & 0.23 & 0.20 & 0.00 & 0.00 & 2.0 & 0.16 & 0.06 & 0.01 & 3.3 & 0.08 & 0.82 & 1.0 \\
\hline upx3-40 m & 2.0 & 0.84 & 0.06 & 0.65 & 3.6 & 0.30 & 0.15 & 0.00 & 2.3 & 0.20 & 1.5 & 1.4 \\
\hline upx2-100m & 1.7 & 0.99 & 0.05 & 0.53 & 6.7 & 0.15 & 0.25 & 0.01 & 0.69 & 0.09 & 2.0 & 1.1 \\
\hline upx2-300 m & 0.85 & 0.77 & 0.26 & 2.4 & 11 & 0.16 & 0.15 & 0.00 & 32 & 0.39 & 1.4 & 3.5 \\
\hline
\end{tabular}

Claustre, H., Hooker, S. B., Van Heukelem, L., Berthon, J.-F., Barlow, R., Ras, J., Sessions, H., Targa, C., Thomas, C. S., van der Linde, D., and Marty, J.-C.: An intercomparison of HPLC phytoplankton pigment methods using in situ samples: application to remote sensing and database activities, Mar. Chem., 85, 41-61, 2004.

Claustre, H., Sciandra, A., and Vaulot, D.: Introduction to the special section bio-optical and biogeochemical conditions in the South East Pacific in late 2004: the BIOSOPE program, Biogeosciences, 5, 679-691, 2008,

http://www.biogeosciences.net/5/679/2008/.

Conte, M. H., Thompson, A., Eglinton, G., and Green, J. C.: Lipid biomarker diversity in the coccolithophorid Emiliania huxleyi (Prymnesiophyceae) and the related species Gephyrocapsa oceanica, J. Phycol., 31, 272-282, 1995.

Conte, M. H., Thompson, A., Lesley, D., and Harris, R. P.: Genetic and physiological influences on the alkenone/alkenoate versus growth temperature relationship in Emiliania huxleyi and Gephyrocapsa Oceanica. Geochim. Cosmochim. Ac., 62, 51-68, 1998.

Conte, M. H., Weber, J. C., King, L. L., and Wakeham, S. G.: The alkenone temperature signal in western North Atlantic surface waters, Geochim. Cosmochim. Ac., 65, 4275-4287, 2001.

Dalsgaard, J., John, M. S., Kattner, G., Müller-Navarra, D., and Hagen, W.: Fatty acid trophic markers in the pelagic marine environment, Adv. Mar. Biol., 46, 225-340, 2003.

Dandonneau, Y., Montel, Y., Blanchot, J., Giraudeau, J., and
Neveux, J.: Temporal variability in phytoplankton pigments, picoplankton and coccolithophores along a transect through the North Atlantic and tropical southwestern Pacific, Deep Sea- Res. Pt. I, 53, 689-712, 2006.

Dijkman, N. A. and Kromkamp, J. C.: Phospholipid-derived fatty acids as chemotaxonomic markers for phytoplankton: application for inferring phytoplankton composition, Mar. Ecol.-Progr. Ser., 324, 113-125, 2006.

DOE: Handbook of Methods for Analysis of the Various Parameters of the Carbon Dioxide System in Seawater; version 2, edited by: Dickson, A. G. and Goyet, C., ORNL/CDIAC-74, 1994.

Eek, M. K., Whiticar, M. J., Bishop, J. K. B., and Wong, C. S.: Influence of nutrients on carbon isotope fractionation by natural populations of Prymnesiophyte algae in NE Pacific. Deep SeaRes. Pt II, 46, 2863-2876, 1999.

Eppley, R. W., Rogers, J. N., and McCarthy, J. J.: Half-saturation constants for uptake of nitrate and ammonium by marine phytoplankton, Limnol. Oceanogr., 14, 912-920, 1969.

Epstein, B. L., D’Hondt, S., Quinn, J. G., Zhang J., and Hargraves, P. E.: An effect of dissolved nutrient concentrations on alkenonebased temperature estimates, Paleoceanography, 13, 122-126, 1998.

Falkowski, P. G.: Physiological responses of phytoplankton to natural light regimes, J. Plankton Res., 6, 295-307, 1984.

Falkowski, P. G., Barber, R. T., and Smetacek, V.: Biogeochemical controls and feedbacks on ocean primary production. Science, 
Table C1. Stable carbon isotopic composition $\left(\delta^{13} \mathrm{C}(\% \circ) \pm\right.$ s.d. of three replicate injections $)$ of selected lipid biomarkers in suspended particles from the South East Pacific Ocean.

\begin{tabular}{|c|c|c|c|c|c|c|c|}
\hline locations-depth (m) & phytol & $\mathrm{C}_{28} \Delta^{5.24(28)^{\mathrm{a}}}$ & $\begin{array}{l}\mathrm{C}_{37: 2} \\
\text { alkenone }\end{array}$ & $\mathrm{C}_{30} \Delta^{22}$ & $n-\mathrm{C}_{17}$ & $\begin{array}{l}\mathrm{C}_{20: 5} \\
\mathrm{FA}\end{array}$ & $\begin{array}{l}i-\mathrm{C}_{15}^{\mathrm{b}} \\
\mathrm{FA}\end{array}$ \\
\hline mar3-50 m & $-28.8 \pm 0.9$ & $-32.4 \pm 0.5$ & $-26.7 \pm 0.5$ & $-26.6 \pm 0.5$ & $-31.7 \pm 0.5$ & $-24.0 \pm 0.5$ & $-20.7 \pm 0.7$ \\
\hline $\begin{array}{l}\text { hnl2-75m } \\
\text { hnl1-100 m }\end{array}$ & $\begin{array}{l}-27.9 \pm 0.5 \\
-30.1 \pm 0.5\end{array}$ & $\begin{array}{l}-34.0 \pm 0.5 \\
-34.0 \pm 0.5\end{array}$ & $-27.1 \pm 0.5$ & $\begin{array}{l}-25.7 \pm 0.5 \\
-26.9 \pm 0.6\end{array}$ & $-33.6 \pm 0.5$ & $-24.8 \pm 0.7$ & $-21.6 \pm 0.5$ \\
\hline $\begin{array}{l}\text { upw1-40 m } \\
\text { upw1-100 m } \\
\text { upw2-300 m }\end{array}$ & $\begin{array}{l}-23.3 \pm 0.5 \\
-23.1\end{array}$ & $\begin{array}{l}-22.0 \pm 0.5 \\
-20.5 \pm 0.5 \\
-23.4 \pm 0.7\end{array}$ & $\begin{array}{l}-23.8 \pm 0.5 \\
-23.8 \pm 0.5\end{array}$ & $\begin{array}{l}-24.7 \pm 0.8 \\
-22.7 \pm 0.5\end{array}$ & $-26.5 \pm 0.5$ & $\begin{array}{l}-24.7 \pm 0.6 \\
-25.0 \pm 0.5 \\
-26.1 \pm 0.5\end{array}$ & $\begin{array}{l}-19.8 \pm 0.5 \\
-19.7 \pm 0.6 \\
-22.1 \pm 0.5\end{array}$ \\
\hline $\begin{array}{l}\text { upx3-40 m } \\
\text { upx2-100 m } \\
\text { upx2-300 m }\end{array}$ & $\begin{array}{l}-31.5 \pm 0.5 \\
-31.1 \pm 2.0 \\
-24.1 \pm 0.7\end{array}$ & $\begin{array}{l}-27.1 \pm 0.9 \\
-22.5 \pm 1.4 \\
-21.3 \pm 0.6\end{array}$ & $\begin{array}{l}-24.9 \pm 0.5 \\
-25.4 \pm 0.5\end{array}$ & $\begin{array}{l}-25.6 \pm 0.5 \\
-23.2 \pm 0.8 \\
-23.3\end{array}$ & $-28.4 \pm 0.5$ & $\begin{array}{l}-28.6 \pm 0.5 \\
-24.2 \pm 0.5 \\
-24.0 \pm 0.5\end{array}$ & $\begin{array}{l}-21.7 \pm 0.5 \\
-19.3 \pm 0.5 \\
-20.4 \pm 0.5\end{array}$ \\
\hline
\end{tabular}

a the major compound 24-methylenecholesterol $\left(\mathrm{C}_{28} \Delta^{5.24(28)}\right)$ stenol was integrated together with their minor stanol pair compound $\left(\mathrm{C}_{28} \Delta^{24(28)}\right)$ to yield a single $\delta^{13} \mathrm{C}$ value for both compounds because of incomplete chromatographic separation.

b 13-methyl-tetradecanoic acid (iso- $\mathrm{C}_{15}$ ).

281, 200-206, 1998.

Freeman, K. H. and Hayes, J. M.: Fractionation of carbon isotopes by phytoplankton and estimates of ancient $\mathrm{CO}_{2}$ levels, Global Biogeochem. Cy., 6, 185-198, 1992.

Freeman, K. H., Hayes, J. M., Trendel, J. M., and Albrecht, P.: Evidence from carbon isotope measurements for diverse origins of sedimentary hydrocarbons, Nature, 343, 254-256, 1990.

Goericke, R., Montoya, J. P., and Fry, B.: Physiology of isotopic fractionation in algae and cyanobacteria. In: Stable Isotopes in Ecology and Environmental Science, Blackwell Science Publishers, 187-221, 1994.

Gómez, F., Claustre, H., Raimbault, P., and Souissi, S.: Two HighNutrient Low-Chlorophyll phytoplankton assemblages: the tropical central Pacific and the offshore Perú-Chile Current, Biogeosciences, 4, 1101-1113, 2007,

http://www.biogeosciences.net/4/1101/2007/.

Goyet, C. and Poisson, A.: New determination of carbonic acid dissociation constants in seawater as a function of temperature and salinity, Deep Sea-Res., 36, 1635-1654, 1989.

Graeve, M., Hagen, W., and Kattner, G.: Herbivorous or omnivorous? On the significance of lipid compositions as trophic markers in Antarctic copepods, Deep Sea-Res., Pt I: 41, 915-924, 1994.

Grice, K., Klein Breteler, W. C. M., Schouten, S., Grossi, V., de
Leeuw, J. W., and Sinninghe Damste, J. S.: Effects of zooplankton herbivory on biomarker proxy records, Paleoceanography, 13, 686-693, 1998.

Grob, C., Ulloa, O., Claustre, H., Huot, Y., Alarcón, G., and Marie, D.: Contribution of picoplankton to the total particulate organic carbon concentration in the eastern South Pacific, Biogeosciences, 4, 837-852, 2007, http://www.biogeosciences.net/4/837/2007/.

Han, J. and Calvin, M.: Hydrocarbon distribution of algae and bacteria, and microbiological activity in sediments, P. Natl. Acad. Sci. USA, 64, 436-443, 1969.

Harada, N., Shin, K. H., Murata, A., Uchida, M., and Nakatani, T.: Characteristics of alkenones synthesized by a bloom of Emiliania huxleyi in the Bering Sea, Geochim. Cosmochim. Ac., 67, 15071519, 2003.

Hayes, J. M.: Factors controlling ${ }^{13} \mathrm{C}$ contents of sedimentary organic compounds: Principles and evidence, Mar. Geol., 113, 111-125, 1993.

Hayes, J. M., Freeman, K. H., Popp, B. N., and Hoham, C. H.: Compound-specific isotopic analyses: A novel tool for reconstruction of ancient biogeochemical processes, Org. Geochem., 16, 1115-1128, 1990.

Hayes, J.M., Fractionation of the isotopes of carbon and hydrogen in biosynthetic processes, edited by: Valley, J. W. and Cole, D. 
R., 2001. Stable Isotope Geochemistry, Reviews in Mineralogy and Geochemistry 43, Mineralogical Society of America, 225278, 2001.

Harvey, H. R., O’Hara, S. C. M., Eglington, G. and Corner, E. D. S.: Biotransformation and assimilation of dietary lipids by Calanus feeding on a dinoflagellate. Geochim. Cosmochim. Ac., 51, 3031-3040, 1987.

Hodgkiss, I. J. and Ho, K. C.: Are changes in N:P ratios in coastal waters the key to increased red tide blooms? Hydrobiologia, 352, 141-147, 1997.

Irwin, A. J., Finkel, Z. V., Schofield, O. M. E., and Falkowski, P. G.: Scaling-up from nutrient physiology to the size-structure of phytoplankton communities, J. Plankton Res., 28, 459-471, 2006.

Jasper, J. and Hayes, J. M.: A carbon isotope record of $\mathrm{CO}_{2}$ levels during the late Quaternary, Nature, 347, 463-465, 1990.

Jones, D. M., Carter, J. F., Eglinton, G., Jumeau, E. J., and Fenwick, C. S.: Determination of $\delta^{\mathrm{xz}} \mathrm{C}$ values of sedimentary straight chain and cyclic alcohols by gas chromatography/isotope ratio mass spectrometry. Biol. Mass Spetrom., 20, 641-646, 1991.

Kaneda, T.: Iso- and anteiso-fatty acids in bacteria: biosynthesis, function, and taxonomic significance, Microbiol. Rev., 55, 288302, 1991

Kroopnick, P. M.: The distribution of $13 \mathrm{C}$ of $\sum \mathrm{CO}_{2}$ in the world oceans, Deep Sea-Res. Pt I, 32, 57-84, 1985.

Laws, E. A., Bidigare, R. R., and Popp, B. N.: Effect of growth rate and $\mathrm{CO}_{2}$ concentration on carbon isotopic fractionation by the marine diatom Phaeodactylum tricornutum. Limnol. Oceanogr., 42, 1552-1560, 1997.

Laws, E. A., Popp, B. N., Bidigare, R. R., Kennicutt, M. C., and Macko, S. A.: Dependence of phytoplankton carbon isotopic composition on growth rate and $\left[\mathrm{CO}_{2}\right]_{\mathrm{aq}}$ : Theoretical considerations and experimental results, Geochim. Cosmochim. Ac., 59, 1131-1138, 1995.

Laws, E. A., Popp, B. N., Bidigare, R. R., Riebesell, U., Burkhardt, S., and Wakeham, S. G.: Controls on the molecular distribution and carbon isotopic composition of alkenones in certain haptophyte algae. Geochem. Geophy. Geosy., 2, paper number:2000GC000057, 2001.

Lee, R. F., Hagen, W., and Kattner, G.: Lipid storage in marine zooplankton. Mar. Ecol.-Progr. Ser., 307, 273-306, 2006.

Lewis, E. and Wallace, D. W. R.: Program Developed for $\mathrm{CO}_{2}$ System Calculations, ORNL/CDIAC-105. Carbon Dioxide Information Analysis Center, Oak Ridge National Laboratory, U.S. Department of Energy, Oak Ridge, Tennessee, 1998.

Litchman, E., Klausmeier, C. A., Miller, J. R., Schofield, O. M. and Falkowski, P. G.: Multi-nutrient, multi-group model of present and future oceanic phytoplankton communities, Biogeosciences, 3, 585-606, 2006, http://www.biogeosciences.net/3/585/2006/.

Livne, A. and Sukenik, A: Lipid synthesis and abundance of acetyl CoA carboxylase in Isochrysis galbana (Prymnesiophyceae) following nitrogen starvation, Plant Cell Physiol. 33, 1175-1181, 1992.

Mackey, M. D., Mackey, D. J., Higgins, H. W., and Wright, S. W.: CHEMTAX - a program for estimating class abundances from chemical markers: application to HPLC measurements of phytoplankton. Mar. Ecol.-Progr. Ser., 144, 265-283, 1996.

McGinn, P. J., Price, G. D., Maleszka, R., and Badger, M. R.: Inorganic Carbon Limitation and Light Control the Expression of
Transcripts Related to the $\mathrm{CO}_{2}$-Concentrating Mechanism in the Cyanobacterium Synechocystis sp. Strain PCC6803. Plant Physiol., 132, 218-229, 2003.

Miquel, J. C., Fowler, S. W., La Rosa, J., and Buat-Menard, P.: Dynamics of the downward flux of particles and carbon in the open northwestern Mediterranean Sea, Deep Sea-Res., 41, 243 261. 1994.

Miquel, J. C., Gasser B., and Claustre, H.: Export Fluxes in Contrasting Environments of the South-East Pacific Ocean Derived from Drifting Sediment traps (BIOSOPE). Eos Trans. AGU. 87(52), Fall Meet. Suppl., Abstract OS13C-1569, 2006.

Mook, W. G., Bommerson, J. C., and Staverman, W. H.: Carbon isotope fractionation between dissolved bicarbonate and gaseous carbon dioxide. Earth Planet. Sc. Lett., 22, 169-176, 1974.

Morel, F. M. M., Reinfelder, J. R., Roberts, S. B., Chamberlain, C. P., Lee, J. G. and Yee, D.: Zinc and carbon co-limitation of marine phytoplankton, Nature, 369, 740-742, 1994.

Muhlebach, A. and Weber, K.: Origins and fate of dissolved sterols in the Weddell Sea, Antarctica. Org. Geochem., 29, 1595-1607, 1998.

Pancost, R. D., Freeman, K. H. and Wakeham, S. G.: Controls on the carbon-isotope compositions of compounds in Peru surface waters, Org. Geochem., 30, 319-340, 1999.

Pancost, R. D., Freeman, K. H., Wakeham, S. G., and Robertson, C. Y.: Controls on carbon isotope fractionation by diatoms in the Peru upwelling region, Geochim. Cosmochim. Ac., 61, 49834991, 1997.

Parrish, C. C., Wells, J. S., Yang, Z., and Dabinett, P.: Growth and lipid composition of scallop juveniles, Placopecten magellanicus, fed the flagellate Isochrysis galbana with varying lipid composition and the diatom Chaetoceros muelleri, Mar. Biol., 133, 461-471, 1998.

Pinturier-Geiss, L., Mejanelle, L., Dale, B., and Karlsen, D. A.: Lipids as indicators of eutrophication in marine coastal sediments, J. Microbiol. Meth., 48, 239-257, 2002.

Popp, B. N., Kenig, F., Wakeham, S. G., Laws, E. A., and Bidigare, R. R.: Does growth rate affect ketone unsaturation and intracellular carbon isotope variability in Emiliania huxleyi? Paleoceanography, 13, 35-41, 1998a.

Popp, B. N., Laws, E. A., Bidigare, R. R., Dore, J. E., Hanson, K. L. and Wakeham, S. G.: Effect of phytoplankton cell geometry on carbon isotopic fractionation. Geochim. Cosmochim. Ac., 62, 69-77, 1998b.

Popp, B. N., Bidigare, R. R., Deschenes, B., Laws, E. A., Prahl, F. G., Tanimoto, J. K., and Wallsgrove, R. J.: A new method for estimating growth rates of alkenone-producing haptophytes, Limnol. Oceanogr. Methods, 4, 114-129, 2006 a.

Popp, B. N., Prahl, F. G., Wallsgrove, R. J., and Tanimoto, J.: Seasonal patterns of alkenone production in the subtropical oligotrophic North Pacific, Paleoceanography, 21, PA1004, doi:10.1029/2005PA001165, 2006b.

Prahl, F.G., Muehlhausen, L.A. and Zahnle, D.L.: Further evaluation of long-chain alkenones as indicators of paleoceanographic conditions. Geochim. Cosmochim. Ac., 52, 2303-2310, 1988.

Prahl, F. G., Sparrow, M. A., and Wolfe, G. V.: Physiological impacts on alkenone paleothermometry, Paleoceanography, 18, 1025, doi:10.1029/2002PA000803, 2003.

Prahl, F. G., Popp, B. N., Karl, D. M., and Sparrow, M. A.: Ecology and biogeochemistry of alkenone production at Station ALOHA, 
Deep Sea- Res. Pt I, 52, 699-719, 2005.

Prahl, F. G., and Wakeham, S. G.: Calibration of unsaturation patterns in long-chain ketone compositions for palaeotemperature assessment, Nature, 330, 367-369, 1987.

Quay, P., Sonnerup, R., Westby, T., Sutsman, J. and McNichol, A.: Changes in the ${ }^{13} \mathrm{C} /{ }^{12} \mathrm{C}$ of dissolved inorganic carbon in the ocean as a tracer of anthropogenic $\mathrm{CO}_{2}$ uptake, Global Biogeochem. Cy., 17(1), 1004, doi:10.1029/2001GB001817, 2003.

Raimbault, P., Garcia, N., and Cerutti, F.: Distribution of inorganic and organic nutrients in the South Pacific Ocean - evidence for long-term accumulation of organic matter in nitrogen-depleted waters, Biogeosciences, 5, 281-298, 2008, http://www.biogeosciences.net/5/281/2008/.

Ras, J., Claustre, H., and Uitz, J.: Spatial variability of phytoplankton pigment distributions in the Subtropical South Pacific Ocean: comparison between in situ and predicted data, Biogeosciences, 5, 353-369, 2008, http://www.biogeosciences.net/5/353/2008/.

Rau, G. H., Chavez, F. P., and Friederich, G. E.: Plankton $13 \mathrm{C} / 12 \mathrm{C}$ variations in Monterey Bay, California: evidence of non-diffusive inorganic carbon uptake by phytoplankton in an upwelling environment, Deep Sea- Res. Pt. I, 48, 79-94, 2001.

Rau, G. H., Riebesell, U., and Wolf-Gladrow, D.: A model of photosynthetic $\mathrm{C}$ fractionation by marine phytoplankton based on diffusive molecular $\mathrm{CO}_{2}$ uptake, Mar. Ecol.-Progr. Ser., 133, 275285, 1996

Reitan, K. I., Rainuzzo, J. R., and Olsen, Y.: Effect of nutrient limitation on fatty acid and lipid content of marine microalgae $1, \mathrm{~J}$. Phycology, 30, 972-979, 1994.

Riebesell, U., Revill, A. T., Holdsworth, D. G., and Volkman, J. K.: The effects of varying $\mathrm{CO}_{2}$ concentration on lipid composition and carbon isotope fractionation in Emiliania huxleyi. Geochim. Cosmochim. Ac., 64, 4179-4192, 2000.

Robinson, N., Eglinton, G., Brassell, S. C., and Cranwell, P. A.: Dinoflagellate origin for sedimentary 4amethylsteroids and $5 \alpha$ (H)-stanols. Nature, 308, 419-422, 1984.

Rontani, J.-F., Marty, J.-C., Miquel, J.-C., and Volkman, J. K.: Free radical oxidation (autoxidation) of alkenones and other microalgal lipids in seawater, Org. Geochem., 37, 354-368, 2006.

Rontani, J.-F., Harji, R., Guasco, S., Prahl, F. G., Volkman, J. K., Bhosle, N. B., and Bonin, P.: Degradation of alkenones by aerobic heterotrophic bacteria: Selective or not?, Org. Geochem., 39, 34-51, 2008.

Rost, B., Zondervan, I., and Riebesell, U.: Light-dependent carbon isotope fractionation in the coccolithophorid Emiliania huxleyi, Limnol. Oceanogr., 47, 120-128, 2002.

Rost, B., Riebesell, U., Burkhardt, S., and Sultemeyer, D.: Carbon acquisition of bloom-forming marine phytoplankton, Limnol. Oceanogr., 48, 55-67, 2003.

Sakata, S., Hayes, J. M., McTaggart, A. R., Evans, R. A., Leckrone, K. J., and Togasaki, R. K.: Carbon isotopic fractionation associated with lipid biosynthesis by a cyanobacterium: Relevance for interpretation of biomarker records, Geochim. Cosmochim. Ac., 61, 5379-5389, 1997.

Sargent, J. R., Gatten, R. R., and Mcintosh, R.: Wax esters in the marine environment - Their occurrence, formation, transformation and ultimate fates, Mar. Chem., 5, 573-584, 1977.

Shaked, Y., Xu, Y., Leblanc, K., and Morel, F. M. M.: Zinc availability and alkaline phosphatase activity in Emiliania hux- leyi: Implications for Zn-P co-limitation in the ocean, Limnol. Oceanogr., 51, 299-309, 2006.

Shifrin, N. S., and Chisholm, S. W.: Phytoplankton lipids: interspecific differences and effects of nitrate, silicate and light-dark cycles, J. Phycology, 17, 374-384, 1981.

Shin, K. H., Hama, T., Yoshie, N., Noriki, S., and Tsunogai, S.: Dynamics of fatty acids in newly biosynthesized phytoplankton cells and seston during a spring bloom off the west coast of Hokkaido Island, Japan. Mar. Chem., 70, 243-256, 2000.

Schouten, S., Klein Breteler, W. C. M., Blokker, P., Schogt, N. C., Rijpstra, W. I., Grice, K., Baas, M., and Sinninghe Damste, J. S.: Biosynthetic effects on the stable carbon isotopic compositions of algal lipids: Implications for deciphering the carbon isotopic biomarker record, Geochim. Cosmochim. Ac., 62, 1397-1406, 1998.

Sicre, M.-A., Bard, E., Ezat, U., and Rostek, F.: Alkenone distributions in the North Atlantic and Nordic sea surface waters, Geochem. Geophy. Geosy., 3(2), 1013 , doi:10.1029/2001GC000159, 2002.

Thompson, P. A. and Calvert, S. E.: Carbon isotope fractionation by Emialiania huxley, Limnol. Oceanogr., 40, 673-679, 1995.

Tolosa, I. and de Mora, S.: Isolation of neutral and acidic lipid biomarker classes for compound-specific-carbon isotope analysis by means of solvent extraction and normal-phase highperformance liquid chromatography, J. Chromatogr. A, 1045, 71-84, 2004.

Tolosa, I., LeBlond, N., Copin-Montegut, C., Marty, J.-C., de Mora, S., and Prieur, L.: Distribution of sterol and fatty alcohol biomarkers in particulate matter from the frontal structure of the Alboran Sea (S. W. Mediterranean Sea), Mar. Chem., 82, 161-183, 2003.

Tolosa, I., Vescovali, I., LeBlond, N., Marty, J.-C., de Mora, S., and Prieur, L.: Distribution of pigment and fatty acid biomarkers in particulae matter from the frontal structure of the Alboran Sea (S. W. Mediterranean Sea). Mar. Chem., 88, 103-125, 2004.

van der Meer, M. T. J., Schouten, S., van Dongen, B. E., Rijpstra, W. I. C., Fuchs, G., Damste, J. S. S., de Leeuw, J. W., and Ward, D. M.: Biosynthetic controls on the ${ }^{13} \mathrm{C}$ contents of organic components in the photoautotrophic bacterium Chloroflexus aurantiacus, J. Biol. Chem., 276, 10971-10976, 2001.

Van Wambeke, F., Obernosterer, I., Moutin, T., Duhamel, S., Ulloa, O., and Claustre, H.: Heterotrophic bacterial production in the eastern South Pacific: longitudinal trends and coupling with primary production, Biogeosciences, 5, 157-169, 2008, http://www.biogeosciences.net/5/157/2008/.

Volkman, J. K.: A review of sterol markers for marine and terrigenous organic matter, Org. Geochem., 9, 83-99, 1986.

Volkman, J. K., Barrerr, S. M., Blackburn, S. I., and Sikes, E. L.: Alkenones in Gephyrocapsa oceanica: Implications for studies of paleoclimate, Geochim. Cosmochim. Ac., 59, 513-520, 1995.

Volkman, J. K., Barrett, S. M., and Dunstan, G. A.: $\mathrm{C}_{25}$ and $\mathrm{C}_{30}$ highly branched isoprenoid alkenes in laboratory cultures of two marine diatoms, Org. Geochem., 21, 407-414, 1994.

Volkman, J. K. and Hallegraeff, G. M.: Lipids in marine diatoms of the genus Thalassiosira: Predominance of 24 methylenecholesterol, Phytochemistry, 27, 1389-1394, 1988.

Volkman, J. K., Jeffrey, S. W., Nichols, P. D., Rogers, G. I., and Garland, C. D.: Fatty acid and lipid composition of 10 species of microalgae used in mariculture, J. Exp. Mar. Biol. Ecol., 128, 
219-240, 1989

Werne, J. P. and Hollander, D. J.: Balancing supply and demand: controls on carbon isotope fractionation in the Cariaco Basin (Venezuela) Younger Dryas to present, Mar. Chem., 92, 275293, 2004.

Winters, K., Parker, P. L., and Van Baalen, C.: Hydrocarbons of Blue-Green Algae: Geochemical significance, Science, 163, 467-468, 1969.

Woodger, F. J., Badger, M. R., and Price, G. D.: Sensing of inorganic carbon limitation in Synechococcus PCC7942 is correlated with the size of the internal inorganic carbon pool and involves oxygen, Plant Physiol., 139, 1959-1969, 2005.
Woodworth, M., Goni, M., Tappa, E., Tedesco, K., Thunell, R., Astor, Y., Varela, R., Rafael Diaz-Ramos, J., and Muller-Karger, F.: Oceanographic controls on the carbon isotopic compositions of sinking particles from the Cariaco Basin, Deep Sea- Res. Pt. I, 51, 1955-1974, 2004.

Yamamoto, M., Shiraiwa, Y., and Inouye, I.: Physiological responses of lipids in Emiliania huxleyi and Gephyrocapsa oceanica (Haptophyceae) to growth status and their implications for alkenone paleothermometry, Org. Geochem., 31, 799-811, 2000. 